\title{
Symposium review: Transition cow calcium homeostasis-Health effects of hypocalcemia and strategies for prevention*
}

\author{
Mirja R. Wilkens, ${ }^{1,2} \odot$ Corwin D. Nelson, ${ }^{3} \dagger \odot$ Laura L. Hernandez, ${ }^{4} \odot$ and Jessica A. A. McArt ${ }^{5} \odot$ \\ ${ }^{1}$ Institute of Physiology and Cell Biology, University of Veterinary Medicine Hannover, Foundation, 30173 Hannover, Germany \\ ${ }^{2}$ Department of Animal Sciences, Sustainable Animal Nutrition Group, University of Goettingen, 37077 Goettingen, Germany \\ ${ }^{3}$ Department of Animal Sciences, University of Florida, Gainesville 32611 \\ ${ }^{4}$ Department of Dairy Science, University of Wisconsin-Madison, 53706 \\ ${ }^{5}$ Department of Population Medicine and Diagnostic Sciences, Cornell University, Ithaca, NY 14853
}

\section{ABSTRACT}

The effects of subclinical hypocalcemia have been explored in numerous observational and mechanistic studies in recent years. Besides obvious, well-known effects on muscle contractility, the role of Ca with respect to immune function and intermediary metabolism explains the contribution of subclinical hypocalcemia to the development of several diseases observed in early lactation and underlines its importance in highperforming dairy cows. The present review aims at integrating recent scientific progress, such as discoveries about the role of the mammary gland in regulating bone mobilization, into generally accepted aspects of the endocrine control of Ca homeostasis. We will discuss Ca transport mechanisms through absorption, resorption, secretion, and mobilization, as well as the physiological regulation of $\mathrm{Ca}$ through parathyroid hormone, 1,25-dihydroxyvitamin $\mathrm{D}$, fibroblast growth factor 23, and serotonin, in addition to dietary mineral requirements. To improve hypocalcemia prevention strategies, our knowledge of the physiological mechanisms necessary to maintain normocalcemia and their endogenous regulation should be combined with data derived from herd-level studies. Using such studies, we will discuss prepartum nutritional strategies aimed at reducing the incidence of subclinical hypocalcemia, as well as options for postpartum Ca supplementation and their effects on early-lactation health and production. Especially in respect to approaches that might interfere with endogenous adaptation processes, such as supple-

Received July 15, 2019.

Accepted November 18, 2019.

*Presented as part of the Animal Health: Transition Cow Calcium Homeostasis-Health Effects of Hypocalcemia and Strategies for Prevention symposium at the ADSA Annual Meeting, Cincinnati, Ohio, June 2019.

†Corresponding author: cdnelson@ufl.edu mentation with vitamin $\mathrm{D}$ metabolites or large doses of $\mathrm{Ca}$, a thorough understanding of the underlying mechanisms that might induce unwanted hypocalcemia rebound effects will be crucial to ameliorate our future management of transition cows. Continued efforts by researchers to understand the interaction of Ca homeostasis with prevention strategies is necessary to optimize cow health and support copious milk production. Key words: dairy cow, hypocalcemia, calcium transport

\section{INTRODUCTION}

Dairy cows have a tremendous and extremely efficient ability to move essential nutrients to milk. Postpartum hypocalcemia is a consequence of initiating a massive draw of $\mathrm{Ca}$ at the onset of lactation. The issue of parturient paresis, commonly known as milk fever, has long been recognized and has been known for nearly a century to result from hypocalcemia. Amazingly, the incidence of milk fever has not increased in the last few decades despite dramatic increases in milk yield per cow (Curtis et al., 1983; Reinhardt et al., 2011). Even so, the occurrence of subclinical hypocalcemia persists. Because several key physiological processes rely on $\mathrm{Ca}$, the effects of subclinical hypocalcemia have substantial negative effects on the health and productivity of dairy cows. Current research efforts are aimed at gaining a better understanding of Ca transport mechanisms and optimizing Ca homeostasis through nutrition and management.

\section{Calcium Fluxes of Periparturient Cows}

At the onset of lactation, the Ca demand of the dairy cow increases dramatically within a very short time. Horst et al. (2005) estimated that in humans and rats, daily Ca losses as a function of metabolic body size (body weight ${ }^{0.75}$ ) at the initiation of milk production ( $5 \mathrm{mg}$ and $200 \mathrm{mg} / \mathrm{kg}^{0.75}$ ) are lower than in late preg- 
nancy $\left(20 \mathrm{mg}\right.$ and $500 \mathrm{mg} / \mathrm{kg}^{0.75}$ ), whereas dairy cows are challenged by a rise from 80 to $500 \mathrm{mg}$ per $\mathrm{kg}^{0.75}$. Even if the exact numbers depend on milk yield, milk Ca content, management during the dry period and the first days in milk, and other factors, the Ca demand of the dairy cow does not decrease but increases substantially at the onset of lactation. Mann et al. (2016) reported an amount of $6.8 \mathrm{~kg}$ of colostrum when the first milking was done 60 min after calving. Given that the $\mathrm{Ca}$ concentration in colostrum is higher than that of mature milk, and circulating Ca amounts to only 2 to $4 \mathrm{~g}$, the plasma pool would have to be exchanged approximately 10 times for the production of $10 \mathrm{~kg}$ of colostrum, but only 3 times for the mineralization of the fetal skeleton. In contrast to horses, for example, renal excretion of $\mathrm{Ca}$ is very low in ruminants (0.5 to $2 \mathrm{~g}$ per day); thus, diminishing urinary Ca loss is not effective in compensating for the sudden increase in $\mathrm{Ca}$ demand, and the readily available Ca pool of the skeleton only contributes 6 to $10 \mathrm{~g}$. To fully counterbalance the enhanced Ca demand, rapid stimulation of further bone mobilization and adaptation of gastrointestinal Ca absorption are needed (Reinhardt et al., 1988; Horst et al., 2005). In the present review, we address the relevance of hypocalcemia, the physiological mechanisms necessary to maintain normocalcemia, their endogenous regulation, and different approaches to improve Ca homeostasis in light of their modes of action.

\section{Physiological Role of Calcium}

The physiological roles of $\mathrm{Ca}$ in bone mineralization, coagulation, cardiac action potentials, cell signaling as a second messenger, and muscle contractility necessitate extremely tight regulation of $\mathrm{Ca}$ in intracellular and extracellular fluids. As such, severe hypocalcemia leads to paresis or death. Even small disturbances in Ca homeostasis can have detrimental effects on muscle, endocrine, and immune function, which likely explain the negative effects of hypocalcemia on health and production of dairy cows.

The role of $\mathrm{Ca}$ in muscle function has significant implications for parturition and gastrointestinal function of periparturient cows. Extracellular $\mathrm{Ca}$ is involved in the excitability of neurons and muscle cells (Han et al., 2015). In smooth muscle, it is especially crucial for the excitation-contraction coupling. Indeed, the role of $\mathrm{Ca}$ in smooth muscle function likely explains the negative effects of hypocalcemia on contractility and motility of the reproductive and gastrointestinal tracts (Daniel, 1983; Al-Eknah and Noakes, 1989; Jørgensen et al., 1998; Heppelmann et al., 2015). In addition, induced subclinical hypocalcemia (SCH; $0.9 \mathrm{mM}$ iCa) by $\mathrm{Na}_{2}$ EDTA infusion decreased chewing activity and DMI of nonlactating dairy cows (Hansen et al., 2003).

The role of $\mathrm{Ca}$ as a second messenger also has significant implications for endocrine and immune functions of periparturient cows. Disturbances to endocrine and immune systems of periparturient cows are recognized as key contributors to diseases and disorders during the periparturient period. Many hormone and immune cell extracellular receptors utilize the inositol trisphosphate intracellular Ca signaling pathway. In neutrophils, for example, inositol trisphosphate released from hydrolysis of phosphatidylinositol 4,5-bisphosphate by phospholipase $\mathrm{C}$ causes release of $\mathrm{Ca}$ stores in the endoplasmic reticulum in response to an immunostimulatory signal. The intracellular Ca efflux from endoplasmic reticulum stores subsequently initiates influx of extracellular $\mathrm{Ca}$ via a stromal interaction molecule and $\mathrm{Ca}$ releaseactivated $\mathrm{Ca}$ channel proteins, in a process known as store-operated Ca entry (Clemens and Lowell, 2015). The increased intracellular $\mathrm{Ca}$ from store-operated $\mathrm{Ca}$ entry triggers several neutrophil functions, including degranulation, chemotaxis, generation of reactive oxygen species, and phagocytosis (Immler et al., 2018). The role of $\mathrm{Ca}$ as a second messenger in immune cells and pancreatic $\beta$-cells presumably explains the observations that induced SCH decreased insulin concentrations and neutrophil activation in dairy cows (Martinez et al., 2014).

\section{Effects of Hypocalcemia on Health and Production}

Whereas parturient paresis is a widely accepted risk factor for subsequent displaced abomasum, ketosis, metritis, retained placenta, mastitis, culling, and decreased milk production, it affects less than $5 \%$ of postpartum cows and thus does not have a large impact on herd-level disease and production outcomes. Subclinical hypocalcemia, however, is less apparent but much more common, thus creating herd-level effects on cow health and production. Recent studies using diagnostic serum or plasma total Ca thresholds ranging from 2.0 to $2.15 \mathrm{mmol} / \mathrm{L}$ at 24 and $48 \mathrm{~h}$ postpartum show that this disorder can affect up to $50 \%$ of postpartum cows (Reinhardt et al., 2011; Martinez et al., 2012). These studies, and others, provide evidence that cows with $\mathrm{SCH}$ are 3 to 5 times more likely to develop postpartum disease and $50 \%$ more likely to be removed from the herd in early lactation than normocalcemic cows (Chapinal et al., 2011; Rodríguez et al., 2017; Venjakob et al., 2018). Interestingly, studies provide mixed results on the effects of $\mathrm{SCH}$ on milk production. This discrepancy might be explained by the evolving classification of SCH epidemiology and diagnosis. 
A recent study by Caixeta et al. (2017) showed that cows with serum total Ca concentrations $\leq 2.15$ $\mathrm{mmol} / \mathrm{L}$ at $\mathrm{d} 1,2$, and 3 in milk, which they termed chronic SCH, had $70 \%$ decreased odds of pregnancy to first service compared with normocalcemic cows. Thus, perhaps it is the persistency of $\mathrm{SCH}$, not the absolute concentration on a given day, that is detrimental to the immediate-postpartum cow. This idea is supported by results from Neves and colleagues (2018a,b), showing that clinically normal cows with low Ca concentrations at calving and 1 DIM are less likely to develop early lactation diseases and produce substantially more milk in early lactation than cows with normal blood $\mathrm{Ca}$ concentrations. Conversely, cows that have persistent SCH lasting until 2 or 4 DIM for primiparous or multiparous cows, respectively, are much more likely to develop additional diseases and have severely reduced milk production compared with their normocalcemic counterparts. Continued mechanistic and epidemiologic investigation into the physiologic mechanisms of $\mathrm{Ca}$ regulation, as discussed below, are underway to determine why some cows are normocalcemic after calving whereas others experience transient or persistent $\mathrm{SCH}$.

\section{CALCIUM TRANSPORT MECHANISMS}

\section{Intestinal and Renal Calcium Absorption and Resorption Mechanisms}

Most of our knowledge about Ca transport mechanisms is derived from studies in rodents. Although various aspects can be extrapolated to ruminants, some peculiarities in comparison to monogastric animals are clear. In the following, specific results obtained in ruminants will be indicated.

Depending on its luminal concentration, the transepithelial electrical gradient, the barrier formed by tight-junction proteins, and the driving force generated by the so-called solvent-drag effect due to the movement of water, gastrointestinal and renal Ca absorption occurs via the transcellular as well as the paracellular pathway (Bronner, 1987; Hoenderop et al., 2005; Goff, 2018). In Caco-2 cells, claudin-2 and claudin- 12 were found to increase the paracellular permeability for $\mathrm{Ca}$ (Fujita et al., 2008). Also in growing goats, stimulation of $\mathrm{Ca}$ homeostatic mechanisms by dietary $\mathrm{Ca}$ restriction resulted in an upregulation of intestinal claudin-2 and claudin-12 expression (Elfers et al., 2016). In the kidney, $70 \%$ of the filtered $\mathrm{Ca}$ is resorbed paracellularly in the proximal tubules, driven mainly by the solventdrag effect (Friedman and Gesek, 1995). Up to $20 \%$ is resorbed in the thick ascending limb of the loop of Henle (Lassiter et al., 1963), where a lumen-positive transepithelial potential difference is generated by the electroneutral uptake of $\mathrm{Na}, \mathrm{K}$, and $\mathrm{Cl}$ via the $\mathrm{Na}^{+}-$ $\mathrm{K}^{+}-2 \mathrm{Cl}^{-}$-cotransporter, followed by the basolateral extrusion of $\mathrm{Cl}$ and the apical secretion of $\mathrm{K}$. The tight junctions contain claudin- 16 that increases cation permeability, claudin-19 that blocks anion permeability, and claudin-14 that decreases the cation permeability mediated by claudin-16 (Negri, 2015).

Active, transcellular Ca transport that mediates $\mathrm{Ca}$ transport in absence of favorable gradients is generally accepted to be a 3 -step process. In the small intestine, Ca enters the cell mainly via the transient receptor potential vanilloid channel type 6 (TRPV6; Peng et al., 1999), is bound to the cytosolic protein calbindin$\mathrm{D}_{9 \mathrm{~K}}\left(\mathrm{CaBP}_{\mathrm{D} 9 \mathrm{~K}} ;\right.$ Bronner, 1987), translocated to the basolateral membrane, and extruded predominantly by the plasma membrane $\mathrm{Ca}^{2+}$-ATPase isoform $1 \mathrm{~b}$ (van Abel et al., 2003). These transport proteins have been detected in the small intestine of sheep, goats, and cows (Yamagishi et al., 2006; Wilkens et al., 2011; Wilkens et al., 2012b; Schröder et al., 2015). In the distal tubule of the kidney, apical uptake of Ca occurs predominantly via transient receptor potential vanilloid channel type 5 (TRPV5; Hoenderop et al., 1999); the transfer to the basolateral cell membrane, where an active sodium-calcium exchanger type 1 (NCX1) exports Ca out of the cell, takes place after binding of $\mathrm{Ca}$ to calbindin- $\mathrm{D}_{28 \mathrm{~K}}$ (Hoenderop et al., 2000). Administration of the biologically active form of vitamin $\mathrm{D}, 1,25$-dihydroxyvitamin $\mathrm{D}\left[\mathbf{1 , 2 5}(\mathrm{OH})_{2} \mathrm{D}_{3}\right]$, induces a significant increase of all the above-mentioned $\mathrm{Ca}$ transport mechanisms except for NCX1 in monogastric species and small ruminants. However, increased endogenous $1,25(\mathrm{OH})_{2} \mathrm{D}_{3}$ as a response to a dietary Ca restriction stimulated intestinal transporter expression and absorption only in goats, but not in sheep. Regarding renal Ca transport, neither a decrease in excretion nor an upregulation of the expression of $\mathrm{Ca}$ transport proteins could be found with a dietary $\mathrm{Ca}$ restriction in small ruminants (Hoenderop et al., 2005; Wilkens et al., 2011; Wilkens et al., 2012b; Herm et al., 2015). Similar studies using cows have not been conducted.

\section{Calcium Absorption from the Rumen}

The comparison of rumen Ca flux rates and mannitol flux rates are used to estimate transepithelial movement of water. The flux rates suggest that the rumen multilayer epithelium is probably too dense to allow significant amounts of $\mathrm{Ca}$ to be absorbed via the interstitial fluid unless the luminal concentration of $\mathrm{Ca}$ is increased dramatically by drenching or providing Ca as a bolus (Schröder and Breves, 2006; Wilkens et 
al., 2011; Wilkens et al., 2012b). Active Ca transport has been demonstrated by functional methods in the rumen of different ruminant species. But as TRPV6 and $\mathrm{CaBP}_{\mathrm{D} 9 \mathrm{~K}}$ are not expressed in ovine, caprine, or bovine rumen epithelia, and neither long-term dietary Ca restriction of sheep and goats nor administration of supraphysiological amounts of $1,25(\mathrm{OH})_{2} \mathrm{D}_{3}$ resulted in increased Ca net flux rates across rumen epithelia measured in Ussing chambers, active Ca transport is probably not mediated by the classical mechanism described for the intestine (Schröder et al., 2001; Wilkens et al., 2011; Wilkens et al., 2012b; Schröder et al., 2015).

Because rumen $\mathrm{Ca}$ transport determined in vitro depends on the presence of short-chain fatty acids (Uppal et al., 2003), an apical transport mechanism based on a $\mathrm{Ca}^{2+} / \mathrm{H}^{+}$exchange system has been discussed but never proven (Lutz and Scharrer, 1991; Schröder et al., 2015). Another candidate for the apical uptake of Ca could be transient receptor potential vanilloid channel type 3 . In vitro and in vivo, agonists of this channel were shown to stimulate not only the transport of $\mathrm{Ca}$ but also that of $\mathrm{NH}_{4}$ and $\mathrm{Na}$ (Rosendahl et al., 2016; Schrapers et al., 2018; Braun et al., 2019). An involvement of a more complex ion-exchange mechanism might also explain the finding that feeding a diet negative in DCAD affects the ratio of the electroneutral to the electrogenic component of rumen $\mathrm{Ca}$ transport from the mucosal to the serosal side determined in Ussing chambers (Wilkens et al., 2016).

Although the mechanism has not been elucidated so far, studies in double-knockout mice have suggested the possibility of an alternative, active intestinal $\mathrm{Ca}$ transport independent of TRPV6 and $\mathrm{CaBP}_{\mathrm{D} 9 \mathrm{~K}}$ (Benn et al., 2008). In rats, Ca absorption mediated by the voltage-gated $\mathrm{Ca}$ channel $\mathrm{Ca}_{\mathrm{v}} 1.3$ that was linked with glucose transport via the sodium-linked glucose transporter 1 could be demonstrated (Morgan et al., 2003; Morgan et al., 2007). Even if glucose-coupled Ca transport does not apply to the rumen, these results demonstrate that other transcellular mechanisms exist apart from the dogma of the classical model described for the small intestine. The recently demonstrated association between hypocalcemia and impaired rumen Ca absorption underlines the relevance of Ca transport in the forestomachs (Hyde et al., 2019), suggesting that further research on this topic is urgently needed.

\section{Calcium Secretion in the Mammary Gland}

During late pregnancy and lactation, the mammary gland differentiates immensely to support the copious production of milk. Milk is the most Ca-rich biological fluid, with $\mathrm{Ca}$ existing in both bound (to casein micelles) and ionized forms (Neville and Watters, 1983; VanHouten and Wysolmerski, 2007). During late pregnancy, activity and expression of Ca transporters, pumps, and modulators are dramatically increased to enable the transcellular movement of Ca from the blood into the milk (Cross et al., 2014). The presence of a calcium sensing receptor (CaSR) on the basolateral side of the mammary epithelium acts to regulate systemic Ca homeostasis during lactation, coordinating a feedback loop to regulate the amounts of $\mathrm{Ca}$ in the milk and the blood (VanHouten and Wysolmerski, 2013). This is one of many examples of the effects of milk synthesis and secretion by the mammary gland affecting maternal homeostasis.

Ionized $\mathrm{Ca}$ is a critical second messenger utilized inside the mammary epithelial cells and must be intracellularly stored, because as a mineral it can be neither synthesized nor degraded. Therefore, cytosolic $\mathrm{Ca}^{2+}$ concentrations must be maintained in a submicromolar range to prevent cellular apoptosis. This is achieved by buffering of $\mathrm{Ca}^{2+}$ in the cytoplasm by $\mathrm{Ca}$ binding proteins, or by intracellular storage of $\mathrm{Ca}$ in the Golgi apparatus by the secretory plasma $\mathrm{Ca}^{2+}$ ATPases (SPCA1/2) and in the endoplasmic reticulum by the sarco(endo)plasmic reticulum ATPases (SERCA; Neville and Watters, 1983; VanHouten and Wysolmerski, 2007; Faddy et al., 2008; Cross et al., 2014). The SPCA, specifically SPCA2, are increased in the mammary gland during pregnancy and lactation and are critical for the contribution of the Golgi apparatus in the enrichment of $\mathrm{Ca}$ by acting to replenish the Golgi with Ca (Faddy et al., 2008). The SERCA are only modestly increased in the mammary gland during pregnancy and lactation, which are critical for replenishing $\mathrm{Ca}$ concentrations in the endoplasmic reticulum (Reinhardt and Horst, 1999). Calcium is transported into the mammary gland transcellularly across the basolateral membrane for milk synthesis and intracellular $\mathrm{Ca}^{2+}$ signaling (Neville and Watters, 1983; VanHouten and Wysolmerski, 2007). Transport of Ca into the mammary gland is thought to occur primarily through a store-operated $\mathrm{Ca}^{2+}$ influx channel (Orai1), by a store-independent mechanism, and is activated by SPCA2 induction (Cross et al., 2013). Several other Ca channels and exchangers are present on the basolateral side of the mammary epithelium; however, Orai1 appears to be the most highly expressed (Cross et al., 2014). Although a portion of $\mathrm{Ca}$ is secreted into milk in the bound form attached to casein micelles, approximately 60 to $70 \%$ of $\mathrm{Ca}$ is actively pumped into milk by the plasma membrane $\mathrm{Ca}^{2+}$ ATPase 2 (PMCA2; Reinhardt et al., 2004; VanHouten et al., 2007). 


\section{Bone Mobilization}

The skeleton contributes to mineral homeostasis by accretion and liberation of $\mathrm{Ca}, \mathrm{P}$, and $\mathrm{Mg}$. In addition, it plays a key role in acid-base balance by buffering $\mathrm{H}^{+}$(Bushinsky et al., 1985). The greater incidence of hypocalcemia observed in higher lactation numbers might be explained by a reduced capacity to mobilize Ca from the skeleton, as the number of osteoclasts and the resorptive bone surface are reduced in older animals (Reinhardt et al., 1988). Mobilization of calcium from bone tissue during lactation is critical for all mammalian species, as dietary $\mathrm{Ca}$ and classical $\mathrm{Ca}$ maintenance mechanisms are unable to compensate for the loss of Ca to milk (Wysolmerski, 2010; Kovacs, 2017). Bone comprises both cortical and trabecular bone tissue; trabecular portions of the bone provide a rapidly exchangeable Ca pool that can be utilized to maintain Ca homeostasis. During lactation, bone mobilization largely occurs in the trabecular-rich sites of the body (spine, proximal femora, and proximal tibias) rather than the purely cortical bones of the body (Kovacs, 2017).

Osteoblasts express receptor activator of $\mathrm{NF \kappa B}$ (RANK) on their surface. Binding of receptor activator NFkB ligand (RANKL) induces the differentiation and maturation of osteoclasts and initiates bone resorption (Boyle et al., 2003). This interaction can be abolished by the osteoblast-derived soluble decoy receptor osteoprotegerin (OPG). Similar to RANK, OPG can bind RANKL and thus decrease the abundance of RANKL available for the activation of RANK. Therefore, the ratio of OPG to RANKL is crucial for the balance between anabolism and catabolism (Trouvin and Goeb, 2010). Continuous exposure to parathyroid hormone (PTH) increases the secretion of RANKL and decreases that of OPG (Ma et al., 2001), a process that is supported by $1,25(\mathrm{OH})_{2} \mathrm{D}_{3}$ by the same mode of action (Kitazawa et al., 2003; Kondo et al., 2004). The observed anabolic effect of $1,25(\mathrm{OH})_{2} \mathrm{D}_{3}$ on bone tissue probably depends on the concomitantly available amount of Ca (Boyce and Weisbrode, 1983). During lactation, mammary secretion of parathyroid hormonerelated protein (PTHrP), acts directly to stimulate osteoclast activation, which acts to increase bone mobilization of Ca (Wysolmerski, 2010). Like PTH, PTHrP exerts its action through an identical receptor on bone tissue. In addition to the activation of osteoclasts to liberate $\mathrm{Ca}$ from bone, osteocytes resorb minerals from their surroundings, thereby increasing lacunar and canalicular spaces during lactation, and are also thought to contribute to Ca mobilization from the bone during this physiological state (Kaya et al., 2017; Kovacs, 2017).

\section{PHYSIOLOGICAL REGULATION OF CA HOMEOSTATIC MECHANISMS}

\section{Parathyroid Hormone, 1,25-Dihydroxyvitamin D, and Fibroblast Growth Factor 23}

A decrease in blood $\mathrm{Ca}^{2+}$ detected by the CaSR of the parathyroid gland induces release of PTH. As this 84 amino acid peptide is stored in secretory granules, it can be secreted in response to hypocalcemia within minutes (Kumar and Thompson, 2011). One of the main actions of continuously elevated PTH plasma concentrations is to stimulate osteoclastogenesis, resulting in mobilization of $\mathrm{Ca}$ and $\mathrm{P}$ from the skeleton via interaction with the OPG-RANKL-RANK signaling system (Ben-awadh et al., 2014). In monogastric animals, PTH also increases renal Ca resorption and phosphate $\left(\mathbf{P}_{\mathbf{i}}\right)$ excretion through direct, rapid mechanisms (Besarab and Swanson, 1982). In addition, PTH stimulates expression and activity of $1 \alpha$-hydroxylase (CYP27B1). This enzyme is predominantly located in the mitochondria of the proximal tubules and converts 25-hydroxyvitamin $\mathrm{D}_{3}\left[\mathbf{2 5}(\mathbf{O H}) \mathbf{D}_{3}\right]$ to the most biologically active vitamin $\mathrm{D}$ metabolite, $1,25(\mathrm{OH})_{2} \mathrm{D}_{3}$ (Fraser and Kodicek, 1973).

The steroid hormone $1,25(\mathrm{OH})_{2} \mathrm{D}_{3}$ binds the intracellular vitamin $\mathrm{D}$ receptor (VDR) and its co-receptor retinoid X receptor (RXR); together they form a ligand-activated transcription factor. The $1,25(\mathrm{OH})_{2} \mathrm{D}_{3}$ hormone is a potent calcitropic agent, resulting in a relatively robust increase in serum Ca within a few hours after injection (Vieira-Neto et al., 2017). Via its genomic effects on $\mathrm{Ca}$ transporter expression that become present after a certain time lag, $1,25(\mathrm{OH})_{2} \mathrm{D}_{3}$ stimulates renal resorption and intestinal absorption of $\mathrm{Ca}$ (Dusso et al., 2005). The $1,25(\mathrm{OH})_{2} \mathrm{D}_{3}$ limits its own synthesis by inhibiting CYP27B1 and stimulating the expression of the 24-hydroxylase (CYP24A1), an enzyme that initiates the inactivation and clearance of both $25(\mathrm{OH}) \mathrm{D}_{3}$ and $1,25(\mathrm{OH})_{2} \mathrm{D}_{3}$ through a hydroxylation at position 24 (Chen and DeLuca, 1995; Beckman and DeLuca, 2002). In addition, $1,25(\mathrm{OH})_{2} \mathrm{D}_{3}$ induces the production of fibroblast growth factor 23 (FGF23; Saji et al., 2010), a bone-derived phosphatonin that interacts with PTH expression and vitamin D metabolism and decreases plasma concentrations of $1,25(\mathrm{OH})_{2} \mathrm{D}_{3}$ (Schiavi and Kumar, 2004; Krajisnik et al., 2007). Furthermore, a direct effect of plasma Ca on $1,25(\mathrm{OH})_{2} \mathrm{D}_{3}$ concentrations has been shown in rats (Bushinsky et al., 1985).

Calcitonin is secreted from the parafollicular or $\mathrm{C}$ cells of the thyroid gland in response to elevated plasma Ca. Although its main action is the inhibition 
of bone resorption during hypercalcemia (Hoff et al., 2002 ), its potential role in the development of hypocalcemia has not received much consideration, due to conflicting research results. Shappell et al. (1987) found lower calcitonin concentrations in multiparous, hypocalcemic cows, whereas no differences were reported by Bandzaite et al. (2005). These discrepancies might occur because alterations in calcitonin could be both cause and consequence of hypocalcemia. Interestingly, it has recently been demonstrated that in contrast to dairy cows experiencing low-grade $\mathrm{SCH}$ (plasma $\mathrm{Ca}$ between 1.88 and $2.13 \mathrm{mmol} / \mathrm{L}$ ), plasma calcitonin is increased transiently in dairy cows developing severe $\mathrm{SCH}$, defined as blood Ca concentrations between 1.50 and $1.85 \mathrm{mmol} / \mathrm{L}$ at calving (Rodríguez et al., 2016). A rise in calcitonin could interfere with PTH-mediated bone resorption and thus induce hypocalcemia.

\section{Dietary Calcium, Magnesium, and Phosphorus}

Because plasma Ca concentration is the key player in stimulating or inhibiting the endocrine regulatory circuits described above, it is not astonishing that a high Ca content in the dry cow ration is a risk factor for hypocalcemia. The compromised capacity to mobilize Ca around calving as a response to high dietary $\mathrm{Ca}$ intake in late gestation was clearly demonstrated by determining the response to $\mathrm{Na}_{2}$ EDTA infusions (van de Braak et al., 1986). In line with these findings, decreasing the $\mathrm{Ca}$ availability in the dry cow ration also resulted in higher plasma concentrations of $1,25(\mathrm{OH})_{2} \mathrm{D}_{3}$ at parturition and improved peripartum Ca homeostasis (Thilsing-Hansen et al., 2002). Meta-analyses revealed that dietary $\mathrm{Ca}$ fed prepartum has a second-order effect on the incidence of hypocalcemia (Oetzel, 1991; Lean et al., 2006). Because the highest incidence of hypocalcemia was observed with intermediate dietary Ca content (1.16 to $1.35 \%$ ), it can be speculated that the negative effect on endocrine adaptation caused by a sufficient $\mathrm{Ca}$ intake prepartum can be overcome by increasing $\mathrm{Ca}$ absorption simply through the enhanced gradients in the gastrointestinal tract due to a very high Ca intake. Experiments with VDR knock out mice kept on so-called "rescue diets" ( $2 \%$ Ca, $1.25 \%$ P, $20 \%$ lactose) have shown that normocalcemia can be maintained without genomic actions of $1,25(\mathrm{OH})_{2} \mathrm{D}_{3}$ if $\mathrm{Ca}$ supply is high (Li et al., 1998).

Insufficient $\mathrm{Mg}$ intake or impaired $\mathrm{Mg}$ absorption have been associated with increased risk for developing hypocalcemia (Lean et al., 2006; Goff, 2008). Low blood concentrations of $\mathrm{Mg}$ can reduce $\mathrm{PTH}$ secretion and, to a certain extent, inhibit the effects of PTH, including the synthesis of $1,25(\mathrm{OH})_{2} \mathrm{D}_{3}$ (Anast et al., 1976; Fatemi et al., 1991). For bone tissues, it has been shown that the production of cyclic adenosine monophosphate (cAMP) induced by the binding of PTH to its receptor, and the Ca mobilizing activity of $1,25(\mathrm{OH})_{2} \mathrm{D}_{3}$, depend on appropriate $\mathrm{Mg}$ concentrations (Freitag et al., 1979; Johannesson and Raisz, 1983).

Feeding a diet high in $\mathrm{P}$ content in late gestation has been demonstrated to have a negative influence on periparturient Ca homeostasis (Peterson et al., 2005; Lean et al., 2006). In a recent study, reducing dietary $\mathrm{P}$ from 0.28 to $0.15 \%$ prepartum resulted in a decrease in plasma $\mathrm{P}_{\mathrm{i}}$ and enhanced concentrations of $\mathrm{Ca}$ and the bone resorption marker CrossLaps before parturition, whereas the decrease in plasma $\mathrm{Ca}$ at parturition was less pronounced. Plasma concentrations of PTH were lower in cows fed $0.15 \% \mathrm{P}$ throughout the observation period, especially with respect to the typical rise immediately after parturition. Plasma $1,25(\mathrm{OH})_{2} \mathrm{D}_{3}$, including its periparturient increase, was not altered by dietary $\mathrm{P}$, despite lower $\mathrm{PTH}$ in cows fed $0.15 \% \mathrm{P}$, indicating that factors other than PTH stimulated $1,25(\mathrm{OH})_{2} \mathrm{D}_{3}$ synthesis or that catabolism of $1,25(\mathrm{OH})_{2} \mathrm{D}_{3}$ was decreased in cows fed $0.15 \%$ P (Cohrs et al., 2018). Low dietary $\mathrm{P}$ intake in healthy men was demonstrated to decrease plasma concentrations of FGF23 and concomitantly increase $1,25(\mathrm{OH})_{2} \mathrm{D}_{3}$ while plasma PTH was low (Antoniucci et al., 2006), and it has been found that RNA expression of FGF23 in bone tissues was diminished in sheep kept on a diet restricted in $\mathrm{P}$ (W. Grünberg, Clinic for Cattle, University of Veterinary Medicine Hannover, Foundation, Hanover, Germany, and M. R. Wilkens, unpublished data). As the activity of CYP27B1 is regulated by the interplay of $\mathrm{Ca}, \mathrm{FGF} 23$, and $\mathrm{PTH}$, the antepartum decrease in plasma $\mathrm{P}_{\mathrm{i}}$ of cows fed the low-P ration likely resulted in decreased FGF23, but the ensuing upregulation of CYP27B1 and suppression of CYP24A1 from low FGF23 (Shimada et al., 2004a,b) was probably counterbalanced by the inhibitory effect of the concomitantly elevated plasma concentrations of $\mathrm{Ca}$ resulting from bone mobilization (Bushinsky et al., 1985). At parturition, this inhibitory effect was abolished as soon as plasma Ca decreased again.

\section{Serotonin}

During the periparturient period, the mammary gland produces and secretes biologically active compounds, including the mineral $\mathrm{Ca}$, which not only affect milk synthesis and secretion, but interact with maternal tissues to coordinate maternal metabolism and physiology. Research in mice and humans has demonstrated that the mammary gland produces $\mathrm{PTHrP}$, which is responsible for regulating bone turnover to support maternal Ca homeostasis during lactation (Wysolmer- 
ski, 2010). Hernandez et al. (2012) demonstrated that serotonin produced by the mammary gland stimulates PTHrP synthesis as well as Ca transport in the mammary gland in a rodent model. Production and secretion of PTHrP from the mammary gland is critical for the bone mobilization necessary to sustain maternal Ca homeostasis during lactation. Initial experiments providing late-lactation dairy cows with 5-hydroxy-Ltryptophan (5-HTP), the immediate precursor to serotonin, resulted in immediate reduction of circulating Ca concentrations (Laporta et al., 2015). Furthermore, 5-HTP treatment immediately decreased total Ca concentrations and resulted in increased milk Ca concentrations and reduced urinary $\mathrm{Ca}$ concentrations. These data suggest that serotonin appears to be directing $\mathrm{Ca}$ movement into the mammary gland for milk synthesis.

In several studies, when prepartum dairy cows were treated with 5-HTP, postpartum total Ca concentrations increased compared with the control (Weaver et al., 2016; Hernández-Castellano et al., 2017; Slater et al., 2018). These data suggested that 5-HTP treatment influences the transport of Ca into milk. Previous data in rodents demonstrated that 5-HTP increased gene and protein expression of PMCA2 on the apical membrane of the mammary epithelium (Laporta et al., 2014a,b). These data were corroborated in dairy cows, where PMCA2 expression is increased in mammary tissue collected from dairy cows treated with 5-HTP (Slater et al., 2018). Additionally, it was determined that 5-HTP treatment influences methylation of promoter regions that result in increased PTHrP expression in the mouse mammary gland (Laporta et al., 2014a; 2014b). These findings suggest that serotonin influences $\mathrm{Ca}$ homeostasis both directly, through methylation of promoter regions influencing mammary $\mathrm{PTHrP}$ production, and indirectly through modulating flux of Ca into the milk, causing bone resorption through negative feedback mechanisms. It has further been demonstrated that serotonin and $\mathrm{Ca}$ homeostasis during the periparturient period appear to regulate $\mathrm{Ca}$ independent of the classical PTH-vitamin D pathway known to regulate Ca homeostasis. In a recent experiment in periparturient dairy cattle, it was demonstrated that no significant changes in serotonin concentrations occur in response to vitamin $\mathrm{D}$ supplementation during the periparturient period (Rodney et al., 2018a). Furthermore, it was also shown that when administering 5-HTP prepartum, not only are postpartum Ca concentrations increased, but no changes appear in PTH concentrations. In the same experiment, cows that had lower postpartum Ca concentrations and did not receive prepartum the 5-HTP treatment showed increased PTH concentrations (Hernández-Castellano et al., 2017). These data support the hypothesis that serotonin appears to regulate
Ca through a different feedback loop than the classical PTH-vitamin D pathway. Research in other mammalian species has consistently supported the notion that Ca homeostasis during lactation is largely regulated by PTHrP rather than PTH; however, this has not been fully elucidated in the dairy cow.

\section{STRATEGIES FOR PREVENTION OF HYPOCALCEMIA}

Many strategies have been tested to mitigate postpartum hypocalcemia, such as use of vitamin D treatments, enteral and parenteral Ca supplementation, and manipulation of dietary $\mathrm{Ca}$ and DCAD. As discussed above, physiological mechanisms to regulate $\mathrm{Ca}$ homeostasis are triggered during periods of low blood Ca concentration. There are multiple ways to initiate prepartum Ca regulation, albeit through different mechanisms, with the goal of a highly responsive homeostatic axis of $\mathrm{Ca}$ regulation in the early postpartum period. Several strategies behind prepartum nutritional prevention of postpartum hypocalcemia utilize the concept of a low blood Ca environment before calving, thus beginning, in essence, a pre-adaptation of the cow to hypocalcemia. Collectively, the strategies to mitigate hypocalcemia have been very effective for prevention of milk fever. Despite the increase in milk yield per cow over the last few decades, the percentage of cows affected by milk fever in US dairy herds has declined from $5.2 \%$ in 2002 and $4.9 \%$ in 2007 to $2.8 \%$ in 2014, according to producer surveys (NAHMS, $2002,2007,2014)$. We attribute the decline in clinical milk fever to implementation of effective prevention strategies. Although each of the strategies we discuss here has demonstrated effectiveness for prevention of clinical milk fever, it also is important to keep in mind that further research is needed in these areas, along with exploration of potential new avenues to decrease risk of $\mathrm{SCH}$.

\section{Low-Calcium Diets}

Feeding of a low-Ca prepartum diet creates a $\mathrm{Ca}$ deficit that stimulates PTH secretion. However, prepartum diets aimed solely at hypocalcemia prevention through low dietary $\mathrm{Ca}$ are difficult to achieve, as they require feeding less than $20 \mathrm{~g}$ of $\mathrm{Ca}$ per day, which is challenging on commercial dairy farms. A low-Ca diet can be achieved more easily through the inclusion of Ca binders in the prepartum diet, most commonly mediated through administration of zeolite A, a synthetic sodium-aluminum silicate. Zeolite A binds $\mathrm{Ca}$, $\mathrm{P}_{\mathrm{i}}$, and $\mathrm{Mg}$ in the rumen and thus creates a diet low in Ca (Thilsing et al., 2006). Recent studies have shown 
that cows fed zeolite A for 2 to 3 wk prepartum have increased serum Ca concentrations during the immediate peripartum period, but none reported differences in postpartum performance (Thilsing-Hansen et al., 2002; Roche et al., 2018; Kerwin et al., 2019). However, all studies enrolled a small number of cows, and larger field trials evaluating health and long-term production when using this method of Ca modulation are necessary. Additional unanswered questions remain regarding the prepartum feeding of zeolite A, including the length of time for which it continues to bind $\mathrm{Ca}$ after cessation of feeding, potential interactions with supplemental administration of oral $\mathrm{Ca}$, and the clinical relevance of the concurrent hypophosphatemia and hypomagnesemia seen during and after feeding (Kerwin et al., 2019).

\section{$D C A D$}

Feeding acidogenic diets prepartum to induce a compensated metabolic acidosis is a proven strategy to minimize postpartum hypocalcemia (Lean et al., 2019; Santos et al., 2019). The principle of a negative DCAD is to create a compensated metabolic acidosis by feeding proportionately stronger anions relative to strong cations. The DCAD of prepartum diets is determined, for the most part, by the $\mathrm{mEq}$ of $\mathrm{Cl}, \mathrm{K}$, $\mathrm{Na}$, and $\mathrm{S}$ ions in the diet using the equation DCAD $=[(\mathrm{mEq}$ of $\mathrm{K})+(\mathrm{mEq}$ of $\mathrm{Na})]-[(\mathrm{mEq}$ of $\mathrm{Cl})+$ (mEq of S)]. Feeding a negative DCAD (i.e., -50 to $-200 \mathrm{mEq} / \mathrm{kg}$ of $\mathrm{DM}$ ) results in partially compensated metabolic acidosis, with a decrease in urine $\mathrm{pH}$ and slight decrease in blood pH (Santos et al., 2019). The effect of a prepartum compensated metabolic acidosis on postpartum Ca homeostasis has been known for a few decades (Ender et al., 1971; Block, 1984). Proper implementation of acidogenic salts in the prepartum ration has substantially minimized the historically high prevalence of clinical hypocalcemia in postpartum dairy cows in the last several decades (Charbonneau et al., 2006; Lean et al., 2006). Santos et al. (2019) and Lean et al. (2019) recently completed meta-analyses on the effects of prepartum DCAD on health and production of dairy cows. The analysis by Santos et al. (2019) reported that feeding a prepartum ration with a DCAD of $-100 \mathrm{mEq} / \mathrm{kg}$ of $\mathrm{DM}$ compared with $+200 \mathrm{mEq} /$ $\mathrm{kg}$ of DM increased FCM yield of multiparous cows by $1 \mathrm{~kg} / \mathrm{d}$, decreased incidence of milk fever in multiparous cows from 12 to $3 \%$, and decreased incidences of retained placenta and metritis in multiparous and primiparous cows. We also note that Santos et al. (2019) observed linear and quadratic responses of health and production to prepartum DCAD. They concluded that feeding a prepartum diet with a negative DCAD improved health and production, but the DCAD probably does not need to be less than $-150 \mathrm{mEq} / \mathrm{kg}$ of DM, based on available data. Similarly, Lean et al. (2019) concluded that a reduction in prepartum DCAD by $200 \mathrm{mEq} / \mathrm{kg}$ of DM, not necessarily a negative DCAD, improved milk production. Notably, milk production of primiparous cows did not benefit from a reduction in DCAD, according to the meta-analyses reported by Lean et al. (2019) and Santos et al. (2019). A simple explanation for the contrast is that multiparous cows experience a greater degree of hypocalcemia compared with primiparous cows. Alternative explanations may be possible but are premature to consider at this time, because data on effects of prepartum DCAD on primiparous cows are sparse.

The mechanisms by which a prepartum negative DCAD contributes to improved Ca homeostasis have not been fully determined, but several good explanations exist. Increased Ca flux from greater renal Ca excretion prepartum is one possible partial explanation of improved postpartum Ca status. In contrast to other herbivores, such as rabbits and horses (Whiting and Quamme, 1984; van Doorn et al., 2004), renal Ca excretion is very low among ruminants and is not altered by restricted dietary supply (Taylor et al., 2009; Herm et al., 2015). The decrease in $\mathrm{pH}$ of the tubular fluid is accompanied by a small increase in proportion of ionized $\mathrm{Ca}$ in blood and an increase in Ca excretion in urine, probably mediated by an inhibition of renal resorption that has been demonstrated for TRPV5 in vitro (Sutton et al., 1979; Yeh et al., 2003). The assumption that this inhibition occurs on the functional level is supported by the observation that, in sheep fed a low DCAD, renal excretion of $\mathrm{Ca}$ is increased irrespective of the Ca content of the ration without any changes in the expression of TRPV5 (A. Liesegang, Institute of Animal Nutrition, Vetsuisse Faculty Zurich, University of Zurich, Switzerland, and M. R. Wilkens, unpublished data). It can be assumed that renal $\mathrm{Ca}$ excretion can be immediately decreased again as soon as the ration is switched to a positive DCAD at calving. Given that a dairy cow kept on a low DCAD ration prepartum excretes approximately 5 to $10 \mathrm{~g}$ of $\mathrm{Ca}$ daily in late gestation (Rodney et al., 2018a; Zimpel et al., 2018), abolishing these losses at calving, when the ration is changed, could substantially improve Ca homeostasis after parturition.

Alterations to gastrointestinal $\mathrm{Ca}$ absorption and bone resorption also may contribute to the beneficial effects of feeding a negative DCAD. Some studies have shown that under acidotic conditions apparent digestibility of Ca increases, probably to compensate for the renal loss (Abu Damir et al., 1994; Schonewille et al., 1994; Roche et al., 2007). However, others reported no or even negative effects on gastrointestinal Ca absorp- 
tion (Leclerc and Block, 1989; Oehlschlaeger et al., 2014). A meta-analysis suggested that the DCAD effect on Ca digestibility could be related to the Ca content of the diet and thus may be more complex (Lomba et al., 1978). This idea is supported by a positive association of luminal $\mathrm{Cl}$ with $\mathrm{Ca}$ transport across rumen epithelia, revealed in Ussing chamber experiments conducted with ovine tissues (Leonhard-Marek et al., 2007), and a change in the ratio of the electrogenic and electroneutral component of the rumen $\mathrm{Ca}$ flux rates from the mucosal to the serosal side, induced by feeding a low DCAD before sacrifice (Wilkens et al., 2016).

A decrease in extracellular $\mathrm{pH}$ activates cultured human osteoclasts that can then be further stimulated by PTH, $1,25(\mathrm{OH})_{2} \mathrm{D}_{3}$, and RANKL (Arnett, 2008). In addition, the capacity of the bone-preserving hormone calcitonin to induce an increase in its second messenger cAMP is decreased with lower $\mathrm{pH}$ in T47D breast cancer cells (Rodríguez et al., 2016). In vivo data on the stimulating effect of acidogenic diets on bone resorption in ruminants are inconsistent. Calcitonin concentrations in serum of cows fed a negative DCAD ration did not differ compared with cows fed a positive-DCAD diet (Romo et al., 1991). Bone resorption, indicated by alterations in respective markers, was observed in some studies (Abu Damir et al., 1994; Liesegang, 2008), but others did not find any effects (Schonewille et al., 1994; Liesegang et al., 2007; Roche et al., 2007; Oehlschlaeger et al., 2014).

Another way a negative DCAD is believed to prepare cows for lactation is by increasing tissue responsiveness to PTH. Goff et al. (2014) fed nonlactating Jersey cows rations with negative $(-188 \mathrm{mEq} / \mathrm{kg}$ of $\mathrm{DM})$ or positive $(188 \mathrm{mEq} / \mathrm{kg}$ of $\mathrm{DM}) \mathrm{DCAD}$ for $14 \mathrm{~d}$, then challenged the cows with intramuscular PTH injections every $3 \mathrm{~h}$ for $48 \mathrm{~h}$. Cows fed the low DCAD had greater serum $\mathrm{Ca}$ and $1,25(\mathrm{OH})_{2} \mathrm{D}_{3}$ concentrations compared with high-DCAD cows from 6 to $48 \mathrm{~h}$ after initiation of the PTH injections. The increased responsiveness to PTH from feeding a negative DCAD occurs soon after decreasing the DCAD. Vieira-Neto et al. (2019) similarly fed nonlactating Holstein cows rations with negative $(-150 \mathrm{mEq} / \mathrm{kg}$ of $\mathrm{DM})$ or positive $(200 \mathrm{mEq} /$ $\mathrm{kg}$ of DM) DCAD, and at $3 \mathrm{~d}$ after start of the DCAD treatment, cows were challenged with an intravenous infusion of PTH for $48 \mathrm{~h}$. Serum total Ca concentrations of negative DCAD cows were increased compared with those of positive DCAD cows $24 \mathrm{~h}$ after the PTH infusion started. One theory for the increased responsiveness to PTH is that decreasing the $\mathrm{pH}$ by feeding rations with a low DCAD alters the conformation of PTH receptors, thereby making the $\mathrm{PTH}$ receptors more sensitive to PTH. In osteoblast-like cells, acidosis results in increased expression and ligand-affinity of PTHR (Disthabanchong et al., 2002). In vivo, feeding a ration with a negative DCAD increased renal PTHR expression in cattle and sheep (Rodríguez et al., 2016; A. Liesegang, Institute of Animal Nutrition, Vetsuisse Faculty Zurich, University of Zurich, Switzerland, and M. R. Wilkens, unpublished data).

Although prepartum DMI will decrease as prepartum DCAD decreases (Charbonneau et al., 2006), Santos et al. (2019) reported that a prepartum negative DCAD increased postpartum DMI. Zimpel et al. (2018) investigated whether the decrease in DMI from feeding acidogenic salts was caused by the inclusion of salts in the diet or acidosis. Their experiment concluded that the decrease in DMI was caused by the compensated metabolic acidosis from feeding acidogenic salts, not from the inclusion of salts.

\section{Vitamin D Nutrition}

Attempts have been made to utilize vitamin $\mathrm{D}$ for prevention and treatment of hypocalcemia in postpartum dairy cows since the discovery that vitamin $\mathrm{D}$ was required for Ca homeostasis. Indeed, George Wallis estimated in 1946 that 12,000 to $15,000 \mathrm{IU} / \mathrm{d}$ of vitamin $\mathrm{D}_{3}$ should be adequate for dairy cows. Several experiments in the 1980s established that feeding 10,000 to 20,000 IU of vitamin $\mathrm{D}_{3}$ was adequate for maintaining $\mathrm{Ca}$ and 25-hydroxyvitamin D $[\mathbf{2 5}(\mathbf{O H}) \mathbf{D}$, refers to combined concentrations of 25-hydroxyvitamin $\mathrm{D}_{2}$ and 25-hydroxyvitamin $\mathrm{D}_{3}$ ] concentrations in serum of lactating dairy cows (Astrup and Nedkvitne, 1987; McDermott et al., 1985), but those experiments did not indicate the vitamin $\mathrm{D}$ requirement to maintain Ca homeostasis of periparturient cows. To this day, properly designed and adequately sized dose titration experiments are still lacking to establish a solid recommendation for vitamin $\mathrm{D}_{3}$ supplementation of dairy cows. The 2001 NRC recommendation for supplemental vitamin $\mathrm{D}_{3}$ for close-up prepartum large-breed (680 kg mature $\mathrm{BW}$ ) cows is $25,000 \mathrm{IU}$ of vitamin $\mathrm{D}_{3} /$ d. In practice, prepartum rations in the United States are reported to provide from $15,000 \mathrm{IU}$ to $100,000 \mathrm{IU}$ of supplemental vitamin $\mathrm{D}_{3} / \mathrm{d}$, but most prepartum rations typically provide 30,000 to $50,000 \mathrm{IU}$ of supplemental vitamin $\mathrm{D}_{3} / \mathrm{d}$, regardless of region or season (Sorge et al., 2013; Nelson et al., 2016; Holcombe et al., 2018). In Europe, regulations restrict supplemental vitamin D to a maximum of 4,000 IU/ $\mathrm{kg}$ of DM (EFSA, 2012), but data on actual practices in Europe are lacking. Experimental evidence is not available to conclude whether current practices for supplemental vitamin $\mathrm{D}_{3}$ are optimal for Ca homeostasis of transition cows, but somewhere between 25,000 
to $50,000 \mathrm{IU}$ of supplemental vitamin $\mathrm{D}_{3} / \mathrm{d}$ should be adequate, on the basis of reported rates of supplemental vitamin $\mathrm{D}_{3}$ in experiments that tested effects of DCAD on postpartum Ca (Santos et al., 2019).

Concentrations of $25(\mathrm{OH}) \mathrm{D}$ in serum or plasma are the best indicator of vitamin $\mathrm{D}$ status of dairy cows. The concentrations of $25(\mathrm{OH}) \mathrm{D}$ in serum or plasma reflect the acquisition of vitamin $\mathrm{D}$ from various sources, whether it be vitamin $D_{2}$ from forages, vitamin $D_{3}$ from endogenous synthesis, or supplemental vitamin $\mathrm{D}_{3}$ (Hymøller and Jensen, 2010,2011). Historically, serum $25(\mathrm{OH}) \mathrm{D}$ concentrations of 20 to $50 \mathrm{ng} / \mathrm{mL}$ were considered normal for cattle (Horst and Littledike, 1982). More recent surveys of serum samples of beef and dairy cows indicate that serum $25(\mathrm{OH}) \mathrm{D}$ concentrations of mature cows are between 40 to $100 \mathrm{ng} / \mathrm{mL}$ with 90 to $95 \%$ as $25(\mathrm{OH}) \mathrm{D}_{3}$ (Nelson et al., 2016). Average serum $25(\mathrm{OH}) \mathrm{D}$ concentrations for most commercial dairy herds receiving 30,000 to 50,000 IU of supplemental vitamin $\mathrm{D}_{3} / \mathrm{d}$ were 60 to $80 \mathrm{ng} / \mathrm{mL}$, regardless of season or time outdoors. Serum 25(OH)D concentrations of postpartum cows were observed to be 5 to $10 \mathrm{ng} / \mathrm{mL}$ less than those of late-lactation and dry cows (Sorge et al., 2013; Holcombe et al., 2018), but even then serum $25(\mathrm{OH}) \mathrm{D}$ concentrations are adequate to prevent clinical hypocalcemia (Vieira-Neto et al., 2017).

Several methods are available for measurement of $25(\mathrm{OH}) \mathrm{D}$ in serum. Data from Holcombe et al. (2018) and Sorge et al. (2013) used the well-established radioimmunoassay (RIA; Heartland Assays, Ames, IA) for $25(\mathrm{OH}) \mathrm{D}$, which includes use of an acetonitrile extraction before the immunoassay. The data reported in Nelson et al. (2016) were from samples measured by RIA, ELISA (VID3K01, Eagle Biosciences, Nashauk, $\mathrm{NH}$ ), and liquid chromatography coupled to mass spectrometry (LC-MS/MS; Heartland Assays). The data from the 3 detection methods were comparable, but extreme caution must be used with serum $25(\mathrm{OH})$ D concentrations measured by ELISA. The LC-MS/ MS detection method is the most reliable and sensitive (Hollis and Horst, 2007). In practice, we recommend validating serum $25(\mathrm{OH}) \mathrm{D}$ results from immune-based assays with LC-MS/MS analysis.

The point regarding vitamin $\mathrm{D}$ status of dairy cows is that serum $25(\mathrm{OH}) \mathrm{D}$ concentrations of dairy cows fed according to current practices indicate that postpartum hypocalcemia does not result from inadequate supplemental vitamin $\mathrm{D}_{3}$. Decades of experiments focused on vitamin $\mathrm{D}$ and prevention of hypocalcemia also have indicated that inadequate supply of vitamin $\mathrm{D}$ is not the driver of hypocalcemia. However, the serum 25(OH) D concentrations that support optimal Ca homeostasis of periparturient cows are unknown, and the ability of cows with below-normal serum $25(\mathrm{OH})$ D (i.e., $<40 \mathrm{ng} /$ $\mathrm{mL}$ ) to fully support the transition to lactation may be impaired. Although most dairy herds in the United States receive 1.5 to 2.5 times the NRC recommendation for supplemental vitamin $\mathrm{D}_{3}$, a minority of herds supplement with less than NRC recommendations. Average serum 25(OH)D concentrations of 2 confined herds of Jersey cows receiving $8,000 \mathrm{IU} / \mathrm{d}$ in the dry period were 32 and $39 \mathrm{ng} / \mathrm{mL}$ (Nelson et al., 2018, unpublished data). In experiments that showed a positive effect of prepartum negative DCAD on postpartum Ca, cows were supplemented with at least 25,000 IU of vitamin $\mathrm{D}_{3}$ in the prepartum ration (Santos et al., 2019). Thus, it is unknown whether supplemental vitamin $\mathrm{D}_{3}$ below $25,000 \mathrm{IU}$ is sufficient for optimum Ca homeostasis, and continued efforts are needed to identify minimum vitamin $\mathrm{D}$ requirements of transition dairy cows.

Recent reports indicate that increasing supplemental vitamin $\mathrm{D}_{3}$ above $60,000 \mathrm{IU} / \mathrm{d}$ likely has few or no benefits for transition $\mathrm{Ca}$, because cows seem to have a limited capacity to convert vitamin $\mathrm{D}_{3}$ to $25(\mathrm{OH})$ $\mathrm{D}_{3}$ (Poindexter et al., 2020). Rodney et al. (2018a) reported that serum $25(\mathrm{OH}) \mathrm{D}_{3}$ concentrations of prepartum cows fed 120,000 IU (3 mg) of vitamin $\mathrm{D}_{3} / \mathrm{d}$ were $60 \mathrm{ng} / \mathrm{mL}$ on average, compared with $237 \mathrm{ng} /$ $\mathrm{mL}$ of cows fed $3 \mathrm{mg}$ of $25(\mathrm{OH}) \mathrm{D}_{3} / \mathrm{d}$. Serum $25(\mathrm{OH})$ D concentrations of lactating cows fed 140,000 IU (3.5 $\mathrm{mg}$ ) of vitamin $\mathrm{D}_{3} / \mathrm{d}$ were $77 \mathrm{ng} / \mathrm{mL}$ after $28 \mathrm{~d}$ on average and were not greater than those of cows fed 60,000 IU (1.5 mg) of vitamin $\mathrm{D}_{3} / \mathrm{d}$ (Poindexter et al., 2020). In contrast, they reported that feeding $1 \mathrm{mg}$ and $3 \mathrm{mg}$ of $25(\mathrm{OH}) \mathrm{D}_{3}$ in addition to $0.5 \mathrm{mg}$ of vitamin $\mathrm{D}_{3}$ for 28 d increased serum $25(\mathrm{OH}) \mathrm{D}_{3}$ to 160 and $260 \mathrm{ng} / \mathrm{mL}$, respectively. The failure of supplemental vitamin $\mathrm{D}_{3}>$ $60,000 \mathrm{IU} / \mathrm{d}$ to substantially increase serum $25(\mathrm{OH}) \mathrm{D}$ indicates that supplemental vitamin $\mathrm{D}_{3}>60,000 \mathrm{IU} / \mathrm{d}$ provides few, if any, benefits to dairy cows.

The increased serum $25(\mathrm{OH}) \mathrm{D}$ from feeding $25(\mathrm{OH})$ $\mathrm{D}_{3}$, on the other hand, offers a promising approach to improving performance of transition cows. Feeding 3 $\mathrm{mg}$ of $25(\mathrm{OH}) \mathrm{D}_{3}$, compared with $3 \mathrm{mg}$ of vitamin $\mathrm{D}_{3}$, increased FCM yield by $4 \mathrm{~kg}$ in the first 49 DIM, decreased incidence of retained placenta, and decreased incidence of metritis (Martinez et al., 2018a,b). The benefits of feeding $25(\mathrm{OH}) \mathrm{D}_{3}$, however, do not seem to result from a substantial improvement in postpartum Ca. Prepartum Ca was increased by feeding $25(\mathrm{OH})$ $\mathrm{D}_{3}$, compared with vitamin $\mathrm{D}_{3}$, but postpartum Ca was not affected by the source of vitamin D (Rodney et al., 2018a). Weiss et al. (2015) also reported that supplementing $6 \mathrm{mg}$ of $25(\mathrm{OH}) \mathrm{D}_{3}$, compared with 0.5 mg of vitamin $\mathrm{D}_{3}$, to prepartum rations with a nega- 
tive DCAD did not affect postpartum Ca. Wilkens et al. (2012a) reported that feeding $3 \mathrm{mg}$ of $25(\mathrm{OH}) \mathrm{D}_{3}$, compared with control, increased prepartum serum $\mathrm{Ca}$, and feeding $3 \mathrm{mg}$ of $25(\mathrm{OH}) \mathrm{D}_{3}$ along with negative DCAD increased postpartum Ca compared with negative DCAD alone. However, in cows kept on a positive DCAD, supplementation with $25(\mathrm{OH}) \mathrm{D}_{3}$ seemed to result in a delay of endogenous adaptation by approximately $12 \mathrm{~h}$. Besides significantly lower Ca concentrations on d 2 postpartum, this was indicated by the observation that both the increase in $1,25(\mathrm{OH})_{2} \mathrm{D}_{3}$, and the typical decrease in $25(\mathrm{OH}) \mathrm{D}$ after parturition, were observed later than in the other groups (Wilkens et al., 2012a). In an experiment with 177 cows fed a prepartum ration with a negative DCAD, Poindexter et al. (2019) reported that cows fed 1 or $3 \mathrm{mg}$ of $25(\mathrm{OH})$ $\mathrm{D}_{3}$ prepartum compared with 1 or $3 \mathrm{mg}$ of vitamin $\mathrm{D}_{3}$ had greater postpartum $\mathrm{Ca}$, but the increment in serum Ca was fairly marginal ( 2.16 vs. $2.12 \pm 0.02 \mathrm{mM}$ ).

In summary, supplementing $25(\mathrm{OH}) \mathrm{D}_{3}$ to achieve superphysiological serum 25(OH)D concentrations in the periparturient period has improved health and performance of dairy cows. Supplementing 25(OH) $\mathrm{D}_{3}$ to prepartum rations with a negative DCAD may lessen risk for $\mathrm{SCH}$, but the effects of $25(\mathrm{OH}) \mathrm{D}_{3}$ on postpartum $\mathrm{Ca}$ are fairly minimal relative to the effects of a prepartum negative DCAD. Immune cells and mammary epithelial cells also utilize $25(\mathrm{OH}) \mathrm{D}_{3}$ (Nelson et al., 2018); so, the benefits of feeding $25(\mathrm{OH}) \mathrm{D}_{3}$ on transition cow health and performance also may be attributed to the extracalcemic functions of vitamin D and not necessarily to improved Ca homeostasis.

\section{Injectable Vitamin D Analogs}

Because hypocalcemia results in part from inadequate $1,25(\mathrm{OH})_{2} \mathrm{D}_{3}$ synthesis or sensitivity, the use of vitamin $\mathrm{D}$ analogs with biological activity provide an appealing opportunity to stimulate Ca transport mechanisms. The $1,25(\mathrm{OH})_{2} \mathrm{D}_{3}$ hormone stimulates a rapid and dramatic increase in serum Ca, but it also is rapidly metabolized and inhibits PTH and CYP27B1 activity. In sheep, 0.5 $\mu \mathrm{g} / \mathrm{kg}$ of BW administered intravenously resulted in a marked increase to maximum levels obtained $16 \mathrm{~h}$ after treatment, followed by a more or less stable elevation for the next 24 to $28 \mathrm{~h}$ (Wilkens et al., 2010). However, a substantial downregulation of CYP27B1 expression has been found, whereas CYP24A1 was significantly induced (Herm et al., 2015). Some promising analogs of $1,25(\mathrm{OH})_{2} \mathrm{D}_{3}$ are the $24-\mathrm{F}-1,25(\mathrm{OH})_{2} \mathrm{D}_{3}$ and $1 \alpha(\mathrm{OH})$ $\mathrm{D}_{3}$ metabolites (Hove et al., 1983; Horst et al., 1990); these analogs had longer half-life and did not require CYP27B1 enzyme activity. For the most part, however, injectable vitamin D analogs are not effective because of the critical timing of administration and disruption of homeostatic feedback loops.

Vieira-Neto et al. (2017) tested the hypothesis that injection of $1,25(\mathrm{OH})_{2} \mathrm{D}_{3}$ soon after parturition would mitigate $\mathrm{SCH}$ if administered to cows fed a negative DCAD ration prepartum. Injection of $200 \mu \mathrm{g}$ of $1,25(\mathrm{OH})_{2} \mathrm{D}_{3}$ within $12 \mathrm{~h}$ of parturition resulted in a sustained increase in serum Ca up to 5 d postpartum, such that serum Ca of treated cows was $2.5 \mathrm{~m} M$ at 2 d postpartum compared with $2.1 \mathrm{~m} M$ in control cows. The treatment also improved postpartum neutrophil function. However, a rebound effect has been observed, such that serum Ca of treated cows was lower than that of control cows from 9 to 15 d postpartum. No effects of treatment were observed on health and production of cows, but the experiment was not powered to assess this outcome. In all, although alternative strategies for use of vitamin D metabolites may eventually prove to be effective, no effective treatments for mitigating the consequences of hypocalcemia using injectable vitamin $\mathrm{D}$ have been demonstrated.

\section{Postpartum Calcium Supplementation}

Given the technological constraints of accurately and economically measuring blood $\mathrm{Ca}$ concentrations on commercial dairy farms, many cows are supplemented with $\mathrm{Ca}$ immediately after calving. Common on-farm interventions include subcutaneous or intravenous administration of $\mathrm{Ca}$ and oral administration of $\mathrm{Ca}$ boluses. The goal of postpartum Ca supplementation is to provide cows with an immediate source of $\mathrm{Ca}$ to cover the time between initiation of homeostatic $\mathrm{Ca}$ regulation mechanisms and return to normocalcemia. Lack of progression to clinical symptoms of recumbency is often used to measure the benefits of these interventions, which is a poor outcome with which to evaluate effectiveness, as clinical hypocalcemia is uncommon. Thus, most studies using this outcome as a measure of association do not have an adequate sample size to find a difference in effectiveness of the intervention, if one truly exists. Other economically important outcomes associated with hypocalcemia, such as the risks of subsequent disease or herd removal, measures of reproductive success, and early-lactation milk yield, should also be considered when evaluating the efficacy of on-farm interventions.

\section{Injectable Calcium}

Use of injectable Ca, most commonly in the form of $23 \% \mathrm{Ca}$ gluconate in the United States, provides 
approximately $10 \mathrm{~g}$ of $\mathrm{Ca}$ in a typical $500-\mathrm{mL}$ bottle. This amount of $\mathrm{Ca}$ administered intravenously is not warranted in cows with $\mathrm{SCH}$, as blood Ca concentrations are not low enough to require this quantity of $\mathrm{Ca}$. Subcutaneous administration is much more common, and blood Ca concentration is increased for at least 12 $\mathrm{h}$ after delivery (Amanlou et al., 2016; Miltenburg et al., 2016; Domino et al., 2017). However, these studies show that, although injectable products given subcutaneously increase blood Ca concentration, they have little effect on the risk of subsequent disease development, milk production, or reproductive performance.

A concern regarding the use of injectable postpartum Ca supplementation, especially with intravenous $\mathrm{Ca}$, is its potential negative effect on Ca homeostasis. Multiple studies (Blanc et al., 2014; Wilms et al., 2019) show a rebound hypocalcemia around $24 \mathrm{~h}$ after administration of intravenous $\mathrm{Ca}$ to immediate postpartum cows that did not express signs of clinical hypocalcemia. It is hypothesized that the rapid increase in blood Ca concentration removes stimulation of PTH secretion and thus dampens the homeostatic response until blood Ca concentrations decrease below a threshold at which they again initiate release of PTH. This is seen, to some degree but not as severely, with subcutaneous $\mathrm{Ca}$ administration as well (Amanlou et al., 2016; Domino et al., 2017).

\section{Oral Calcium}

Oral $\mathrm{Ca}$ is often administered in bolus form, with most commercial products containing 40 to $50 \mathrm{~g}$ of elemental $\mathrm{Ca}$ per bolus or set of boluses intended to be given as a single dose; some products recommend a second dose $12 \mathrm{~h}$ later. These products contain differing combinations of rapidly and slowly absorbed Ca salts. The benefit of rapidly absorbed salts, such as Ca chloride, is that they are both highly bioavailable and acidifying (supporting mobilization of the cow's own Ca stores); however, they are irritating to oral mucous membranes and must be administered in a manner that prevents extended contact with the oral, pharyngeal, and esophageal mucosa. Slowly absorbed Ca salts (such as Ca propionate, Ca sulfate, and Ca carbonate) either have an equivalent efficacy and longer duration of action than quickly absorbed Ca salts (Ca propionate) or are ineffective as an immediate Ca source due to their poor bioavailability (Ca sulfate, Ca carbonate; Goff and Horst, 1993).

The goal of oral $\mathrm{Ca}$ administration is to provide a large quantity of $\mathrm{Ca}$ that is absorbed over a longer period, resulting in a steady and prolonged increase in blood $\mathrm{Ca}$ concentration compared with injectable products. Although studies agree that oral Ca increases blood Ca concentration, the duration of increase postadministration varies from 1 to $24 \mathrm{~h}$, likely due to product composition, dosage, and frequency of administration, as well as the production capacity of the cows under study (Blanc et al., 2014; Martinez et al., 2016a; Domino et al., 2017; Leno et al., 2018; Valldecabres et al., 2018). It is interesting that this short-term change in blood $\mathrm{Ca}$ concentration can have effects on cow health and production. However, these effects are not always beneficial, and most studies do not recommend their use as a blanket treatment, especially in primiparous cows (Oetzel and Miller, 2012; Martinez et al., 2016a,b; Domino et al., 2017; Valldecabres et al., 2018). Conversely, these same studies provide good evidence of the value of oral Ca supplementation to older cows and those with a greater production potential. It is thus important to take into account the formulation of oral Ca boluses, the timing and frequency with which they are administered, and cow-level variables when using oral $\mathrm{Ca}$ for treatment or prevention of hypocalcemia in dairy cows.

\section{PRACTICAL APPLICATIONS}

As discussed, strong evidence exists that feeding a low-DCAD diet prepartum improves postpartum $\mathrm{Ca}$ status in multiparous cows, with concomitant improvements in health and production outcomes (Lean et al., 2019; Santos et al., 2019). Practically, the feeding of such a diet requires constant monitoring and maintenance, the specifics of which are beyond the scope of this review. However, without appropriate balancing of a consistent diet, it is difficult to achieve the beneficial effects of a low-DCAD diet. In addition, cow comfort in the close-up pens is of utmost importance, with specific attention to management of stocking density, heat abatement, and cow movement patterns, as these factors are essential for optimized DMI throughout the close-up period. However, even with focused attention on the appropriate feeding of a low-DCAD diet prepartum, high incidence of $\mathrm{SCH}$ still exists. To continue prevention of SCH postpartum, use of oral Ca has the most supporting evidence of beneficial effects when administered to older cows and those likely to experience a decrease in DMI postpartum, such as lame cows. It is not recommended to give postpartum $\mathrm{Ca}$ supplementation to primiparous cows, and administration of intravenous $\mathrm{Ca}$ is particularly detrimental in the prevention of $\mathrm{SCH}$. As we continue our investigation of the mechanisms of $\mathrm{Ca}$ regulation in high-producing dairy cows, we must use this information to provide practical and economically viable recommendations to 
dairy producers, nutritionists, and veterinarians that optimize and support a cow's ability to transition into lactation while maintaining health and production.

\section{FUTURE DIRECTIONS}

Advanced and quickly developing technologies for genotyping and breeding based on genetic information present new tools to prevent hypocalcemia. Recent studies have reported a heritability of macromineral disorders and plasma concentrations of $\mathrm{Ca}$ and $\mathrm{P}_{\mathrm{i}}$, within the first days after parturition, in the ranges of 0.23 to 0.32 and 0.30 to 0.40 , respectively (Tsiamadis et al., 2016a,b). In other species, vitamin D status and plasma Ca have been shown to be related to polymorphisms in genes coding for receptors, enzymes, and transport proteins involved in vitamin $\mathrm{D}$ metabolism and mineral homeostasis (Laaksonen et al., 2009; Jolliffe et al., 2016). In dairy cows, several SNP associated with genes involved in vitamin D signaling have already been identified to be associated with hypocalcemia (Deiner et al., 2012; Pacheco et al., 2018).

Despite intense research efforts in past decades and in recent years to solve the issue of hypocalcemia in dairy cows, several key gaps in knowledge remain. With respect to beneficial and potential adverse effects of supplementation with vitamin $\mathrm{D}$ metabolites and $\mathrm{Ca}$, the exact mechanisms responsible for the observed rebound effects and the relevance of vitamin D metabolites hydroxylated at position 24 should be elucidated. In rats, treatment with $24,25(\mathrm{OH})_{2} \mathrm{D}_{3}$ decreased bone resorption (Mortensen et al., 1993). In cows, a negative correlation between $\mathrm{Ca}$ and endogenous $24,25(\mathrm{OH})_{2} \mathrm{D}_{3}$ was found in animals suffering from parturient paresis, and treatment with $24,25(\mathrm{OH})_{2} \mathrm{D}_{3}$ increased the incidence of clinical hypocalcemia (Smith et al., 1982; Barton et al., 1984).

Another critical aspect is a thorough understanding of the contribution of gastrointestinal tract $\mathrm{Ca}$ absorption and skeletal resorption to meeting the Ca demands of lactation. To date, the exact mechanisms of $\mathrm{Ca}$ absorption in the gastrointestinal tract of cows before and during lactation remain unclear. Nevertheless, the interactions between different nutrients and minerals play pivotal roles and might lead to the inconsistent results found in herd-level studies. The extent of bone loss to restore $\mathrm{Ca}$ homeostasis postpartum, whether skeletal mineralization is completely restored during lactation, and the degree to which bone resorption capacity changes with age also remain unclear. Nutrition and management factors affecting Ca homeostasis that still need further elucidation to optimize postpartum Ca include identifying the optimum level of DCAD; source and inclusion of dietary $\mathrm{Ca}, \mathrm{P}$, and $\mathrm{Mg}$; source and dose of supplemental vitamin $\mathrm{D}$; and management of high-risk versus low-risk animals for treatment and prevention of hypocalcemia. Recent studies reported not only influence of dietary protein on vitamin D metabolism (Wilkens et al., 2018) but also interactions between Ca homeostasis, bone mobilization, pathways regulating intermediary metabolism, and IGF1 (Rodney et al., 2018b). From studies in humans and mice, it is known that bone-derived factors such as osteocalcin, especially its undercarboxylated form, which has been demonstrated to control physiological processes in an endocrine manner, interfere with glucose metabolism (Lin et al., 2018). Many uncertainties exist among these areas that allow for opportunities to optimize postpartum Ca homeostasis and, consequently, health and productivity of dairy cows.

\section{ACKNOWLEDGMENTS}

The authors have not stated any conflicts of interest.

\section{REFERENCES}

Abu Damir, H., M. Phillippo, B. H. Thorp, J. S. Milne, L. Dick, and I. M. Nevison. 1994. Effects of dietary acidity on calcium balance and mobilisation, bone morphology and 1,25 dihydroxyvitamin D in prepartal dairy cows. Res. Vet. Sci. 56:310-318. https://doi.org/ 10.1016/0034-5288(94)90147-3.

Al-Eknah, M. M., and D. E. Noakes. 1989. A preliminary study on the effect of induced hypocalcaemia and nifedipine on uterine activity in the parturient cow. J. Vet. Pharmacol. Ther. 12:237-239. https: //doi.org/10.1111/j.1365-2885.1989.tb00666.x.

Amanlou, H., A. P. Akbari, N. E. Farsuni, and N. Silva-Del-Rio. 2016 Effects of subcutaneous calcium administration at calving on mineral status, health, and production of Holstein cows. J. Dairy Sci. 99:9199-9210. https://doi.org/10.3168/jds.2015-10844.

Anast, C. S., J. L. Winnacker, L. R. Forte, and T. W. Burns. 1976 Impaired release of parathyroid hormone in magnesium deficiency. J. Clin. Endocrinol. Metab. 42:707-717. https://doi.org/10.1210/ jcem-42-4-707.

Antoniucci, D. M., T. Yamashita, and A. A. Portale. 2006. Dietary phosphorus regulates serum fibroblast growth factor-23 concentrations in healthy men. J. Clin. Endocrinol. Metab. 91:3144-3149. https://doi.org/10.1210/jc.2006-0021.

Arnett, T. R. 2008. Extracellular pH regulates bone cell function. J. Nutr. 138:415S-418S. https://doi.org/10.1093/jn/138.2.415S.

Astrup, H. N., and J. J. Nedkvitne. 1987. Effects of vitamin D supplement on cows and sheep. Nor. J. Agric. Sci. 1:87-95.

Bandzaite, V., I. Klimiene, V. Spakauskas, and A. Matusevicius. 2005. Interaction between the levels of hormones and minerals in sera of healthy and sick cows. Pol. J. Vet. Sci. 8:269-274.

Barton, B. A., D. W. Hodnett, N. A. Jorgensen, and H. F. DeLuca. 1984. 24,25-Dihydroxyvitamin $\mathrm{D}_{3}$ administration increases incidence of parturient paresis. J. Dairy Sci. 67:1236-1239. https:// doi.org/10.3168/jds.S0022-0302(84)81429-0.

Beckman, M. J., and H. F. DeLuca. 2002. Regulation of renal vitamin $\mathrm{D}$ receptor is an important determinant of $1 \alpha, 25$-dihydroxyvitamin $\mathrm{D}_{3}$ levels in vivo. Arch. Biochem. Biophys. 401:44-52. https://doi .org/10.1016/S0003-9861(02)00010-3.

Ben-awadh, A. N., J. Delgado-Calle, X. Tu, K. Kuhlenschmidt, M. R. Allen, L. I. Plotkin, and T. Bellido. 2014. Parathyroid hormone receptor signaling induces bone resorption in the adult skeleton by directly regulating the RANKL gene in osteocytes. Endocrinology 155:2797-2809. https://doi.org/10.1210/en.2014-1046. 
Benn, B. S., D. Ajibade, A. Porta, P. Dhawan, M. Hediger, J. B. Peng, Y. Jiang, G. T. Oh, E. B. Jeung, L. Lieben, R. Bouillon, G. Carmeliet, and S. Christakos. 2008. Active intestinal calcium transport in the absence of transient receptor potential vanilloid type 6 and calbindin-D9k. Endocrinology 149:3196-3205. https:// doi.org/10.1210/en.2007-1655.

Besarab, A., and J. W. Swanson. 1982. Differences in effects of aminoterminal and intact parathyroid hormone on calcium, phosphate, and cAMP excretion by the isolated perfused rat kidney. Ren. Physiol. 5:261-271. https://doi.org/10.1159/000172866.

Blanc, C. D., M. Van der List, S. S. Aly, H. A. Rossow, and N. Silvadel-Rio. 2014. Blood calcium dynamics after prophylactic treatment of subclinical hypocalcemia with oral or intravenous calcium. J. Dairy Sci. 97:6901-6906. https://doi.org/10.3168/jds.2014-7927.

Block, E. 1984. Manipulating dietary anions and cations for prepartum dairy cows to reduce incidence of milk fever. J. Dairy Sci. 67:29392948. https://doi.org/10.3168/jds.S0022-0302(84)81657-4.

Boyce, R. W., and S. E. Weisbrode. 1983. Effect of dietary calcium on the response of bone to $1,25(\mathrm{OH})_{2} \mathrm{D}_{3}$. Lab. Invest. 48:683-689.

Boyle, W. J., W. S. Simonet, and D. L. Lacey. 2003. Osteoclast differentiation and activation. Nature 423:337-342. https://doi.org/ 10.1038/nature01658.

Braun, H. S., K. T. Schrapers, K. Mahlkow-Nerge, F. Stumpff, and J. Rosendahl. 2019. Dietary supplementation of essential oils in dairy cows: Evidence for stimulatory effects on nutrient absorption. Animal 13:518-523. https://doi.org/10.1017/S1751731118001696.

Bronner, F. 1987. Intestinal calcium absorption: Mechanisms and applications. J. Nutr. 117:1347-1352. https://doi.org/10.1093/jn/ 117.8.1347.

Bushinsky, D. A., G. S. Riera, M. J. Favus, and F. L. Coe. 1985. Evidence that blood ionized calcium can regulate serum $1,25(\mathrm{OH})_{2} \mathrm{D}_{3}$ independently of parathyroid hormone and phosphorus in the rat. J. Clin. Invest. 76:1599-1604. https://doi.org/10.1172/JCI112143.

Caixeta, L. S., P. A. Ospina, M. B. Capel, and D. V. Nydam. 2017. Association between subclinical hypocalcemia in the first 3 days of lactation and reproductive performance of dairy cows. Theriogenology 94:1-7. https://doi.org/10.1016/j.theriogenology.2017.01 .039 .

Chapinal, N., M. Carson, T. F. Duffield, M. Capel, S. Godden, M. Overton, J. E. Santos, and S. J. LeBlanc. 2011. The association of serum metabolites with clinical disease during the transition period. J. Dairy Sci. 94:4897-4903. https://doi.org/10.3168/jds $.2010-4075$

Charbonneau, E., D. Pellerin, and G. R. Oetzel. 2006. Impact of lowering dietary cation-anion difference in nonlactating dairy cows: A meta-analysis. J. Dairy Sci. 89:537-548. https://doi.org/10.3168/ jds.S0022-0302(06)72116-6.

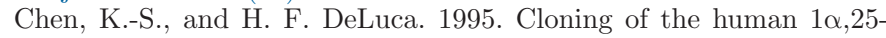
dihydroxyvitamin $\mathrm{D}_{3}$ 24-hydroxylase gene promoter and identification of two vitamin D-responsive elements. Biochim. Biophys. Acta 1263:1-9. https://doi.org/10.1016/0167-4781(95)00060-T.

Clemens, R. A., and C. A. Lowell. 2015. Store-operated calcium signaling in neutrophils. J. Leukoc. Biol. 98:497-502. https://doi.org/10 $.1189 /$ jlb.2MR1114-573R.

Cohrs, I., M. R. Wilkens, and W. Grünberg. 2018. Short communication: Effect of dietary phosphorus deprivation in late gestation and early lactation on the calcium homeostasis of periparturient dairy cows. J. Dairy Sci. 101:9591-9598. https://doi.org/10.3168/ jds.2018-14642.

Cross, B. M., G. E. Breitwieser, T. A. Reinhardt, and R. Rao. 2014. Cellular calcium dynamics in lactation and breast cancer: From physiology to pathology. Am. J. Physiol. Cell Physiol. 306:C515C526. https://doi.org/10.1152/ajpcell.00330.2013.

Cross, B. M., A. Hack, T. A. Reinhardt, and R. Rao. 2013. SPCA2 regulates Orail trafficking and store independent $\mathrm{Ca}^{2+}$ entry in a model of lactation. PLoS One 8:e67348. https://doi.org/10.1371/ journal.pone.0067348.

Curtis, C. R., H. N. Erb, C. J. Sniffen, R. D. Smith, P. A. Powers, M. C. Smith, M. E. White, R. B. Hillman, and E. J. Pearson. 1983. Association of parturient hypocalcemia with eight periparturient disorders in Holstein cows. J. Am. Vet. Med. Assoc. 183:559-561.
Daniel, R. C. 1983. Motility of the rumen and abomasum during hypocalcaemia. Can. J. Comp. Med. 47:276-280.

Deiner, C., M. Reiche, D. Lassner, D. Grienitz, S. Twardziok, A. Moesch, P. Wenning, and H. Martens. 2012. Allelic variations in coding regions of the vitamin $\mathrm{D}$ receptor gene in dairy cows and potential susceptibility to periparturient hypocalcaemia. J. Dairy Res. 79:423-428. https://doi.org/10.1017/S0022029912000465.

Disthabanchong, S., K. J. Martin, C. L. McConkey, and E. A. Gonzalez. 2002. Metabolic acidosis up-regulates PTH/PTHrP receptors in UMR 106-01 osteoblast-like cells. Kidney Int. 62:1171-1177. https://doi.org/10.1111/j.1523-1755.2002.kid568.x.

Domino, A. R., H. C. Korzec, and J. A. A. McArt. 2017. Field trial of 2 calcium supplements on early lactation health and production in multiparous Holstein cows. J. Dairy Sci. 100:9681-9690. https:// doi.org/10.3168/jds.2017-12885.

Dusso, A. S., A. J. Brown, and E. Slatopolsky. 2005. Vitamin D. Am. J. Physiol. Renal. Physiol. 289:F8-F28.

EFSA (European Food Safety Authority). 2012. Scientific opinion on the safety and efficacy of vitamin D3 (cholecalciferol) as a feed additive for chickens for fattening, turkeys, other poultry, pigs, piglets (suckling), calves for rearing, calves for fattening, bovines, ovines, equines, fish and other animal species or categories, based on a dossier submitted by DSM. EFSA J. 10:2968-2993.

Elfers, K., I. Marr, M. R. Wilkens, G. Breves, M. Langeheine, R. Brehm, and A. S. Muscher-Banse. 2016. Expression of tight junction proteins and cadherin 17 in the small intestine of young goats offered a reduced $\mathrm{N}$ and/or Ca diet. PLoS One 11:e0154311. https: //doi.org/10.1371/journal.pone.0154311.

Ender, F., I. W. Dishington, and A. Helgebostad. 1971. Calcium balance studies in dairy cows under experimental induction and prevention of hypocalcaemic paresis puerperalis. Z. Tierphysiol. Tierernahr. Futtermittelkd. 28:233-256. https://doi.org/10.1111/ j.1439-0396.1971.tb01573.x.

Faddy, H. M., C. E. Smart, R. Xu, G. Y. Lee, P. A. Kenny, M. Feng, R. Rao, M. A. Brown, M. J. Bissell, S. J. Roberts-Thomson, and G. R. Monteith. 2008. Localization of plasma membrane and secretory calcium pumps in the mammary gland. Biochem. Biophys. Res. Commun. 369:977-981. https://doi.org/10.1016/j.bbrc.2008 .03.003.

Fatemi, S., E. Ryzen, J. Flores, D. B. Endres, and R. K. Rude. 1991. Effect of experimental human magnesium depletion on parathyroid hormone secretion and 1,25-dihydroxyvitamin D metabolism. J. Clin. Endocrinol. Metab. 73:1067-1072. https://doi.org/10 .1210/jcem-73-5-1067.

Fraser, D. R., and E. Kodicek. 1973. Regulation of 25-hydroxycholecalciferol-1-hydroxylase activity in kidney by parathyroid hormone. Nat. New Biol. 241:163-166. https://doi.org/10.1038/ newbio241163a0.

Freitag, J. J., K. J. Martin, M. B. Conrades, E. Bellorin-Font, S. Teitelbaum, S. Klahr, and E. Slatopolsky. 1979. Evidence for skeletal resistance to parathyroid hormone in magnesium deficiency. Studies in isolated perfused bone. J. Clin. Invest. 64:1238-1244. https: //doi.org/10.1172/JCI109578.

Friedman, P. A., and F. A. Gesek. 1995. Cellular calcium transport in renal epithelia: Measurement, mechanisms, and regulation. Physiol. Rev. 75:429-471. https://doi.org/10.1152/physrev.1995 .75.3.429.

Fujita, H., K. Sugimoto, S. Inatomi, T. Maeda, M. Osanai, Y. Uchiyama, Y. Yamamoto, T. Wada, T. Kojima, H. Yokozaki, T. Yamashita, S. Kato, N. Sawada, and H. Chiba. 2008. Tight junction proteins claudin-2 and -12 are critical for vitamin D-dependent $\mathrm{Ca}^{2+}$ absorption between enterocytes. Mol. Biol. Cell 19:19121921. https://doi.org/10.1091/mbc.e07-09-0973.

Goff, J. P. 2008. The monitoring, prevention, and treatment of milk fever and subclinical hypocalcemia in dairy cows. Vet. J. 176:50-57. https://doi.org/10.1016/j.tvjl.2007.12.020.

Goff, J. P. 2018. Invited review: Mineral absorption mechanisms, mineral interactions that affect acid-base and antioxidant status, and diet considerations to improve mineral status. J. Dairy Sci. 101:2763-2813. https://doi.org/10.3168/jds.2017-13112. 
Goff, J. P., and R. L. Horst. 1993. Oral administration of calcium salts for treatment of hypocalcemia in cattle. J. Dairy Sci. 76:101-108. https://doi.org/10.3168/jds.S0022-0302(93)77328-2.

Goff, J. P., A. Liesegang, and R. L. Horst. 2014. Diet-induced pseudohypoparathyroidism: A hypocalcemia and milk fever risk factor. J. Dairy Sci. 97:1520-1528. https://doi.org/10.3168/jds.2013-7467.

Han, P., B. J. Trinidad, and J. Shi. 2015. Hypocalcemia-induced seizure: Demystifying the calcium paradox. ASN Neuro 7. https://doi .org/10.1177/1759091415578050.

Hansen, S. S., P. Norgaard, C. Pedersen, R. J. Jorgensen, L. S. Mellau, and J. D. Enemark. 2003. The effect of subclinical hypocalcaemia induced by $\mathrm{Na}_{2}$ EDTA on the feed intake and chewing activity of dairy cows. Vet. Res. Commun. 27:193-205. https://doi.org/10 .1023/A:1023340506782.

Heppelmann, M., K. Krach, L. Krueger, P. Benz, K. Herzog, M. Piechotta, M. Hoedemaker, and H. Bollwein. 2015. The effect of metritis and subclinical hypocalcemia on uterine involution in dairy cows evaluated by sonomicrometry. J. Reprod. Dev. 61:565569. https://doi.org/10.1262/jrd.2015-015.

Herm, G., A. S. Muscher-Banse, G. Breves, B. Schröder, and M. R. Wilkens. 2015. Renal mechanisms of calcium homeostasis in sheep and goats. J. Anim. Sci. 93:1608-1621. https://doi.org/10.2527/ jas.2014-8450.

Hernandez, L. L., K. A. Gregerson, and N. D. Horseman. 2012. Mammary gland serotonin regulates parathyroid hormone-related protein and other bone-related signals. Am. J. Physiol. Endocrinol. Metab. 302:E1009-E1015. https://doi.org/10.1152/ajpendo.00666 .2011 .

Hernández-Castellano, L. E., L. L. Hernandez, H. Sauerwein, and R. M. Bruckmaier. 2017. Endocrine and metabolic changes in transition dairy cows are affected by prepartum infusions of a serotonin precursor. J. Dairy Sci. 100:5050-5057. https://doi.org/10.3168/ jds.2016-12441.

Hoenderop, J. G., B. Nilius, and R. J. Bindels. 2005. Calcium absorption across epithelia. Physiol. Rev. 85:373-422. https://doi.org/10 .1152 /physrev.00003.2004.

Hoenderop, J. G., A. W. van der Kemp, A. Hartog, S. F. van de Graaf, C. H. van Os, P. H. Willems, and R. J. Bindels. 1999. Molecular identification of the apical $\mathrm{Ca}^{2+}$ channel in 1, 25-dihydroxyvitamin $\mathrm{D}_{3}$-responsive epithelia. J. Biol. Chem. 274:8375-8378. https://doi .org/10.1074/jbc.274.13.8375.

Hoenderop, J. G., P. H. Willems, and R. J. M. Bindels. 2000. Toward a comprehensive molecular model of active calcium reabsorption. Am. J. Physiol. Renal Physiol. 278:F352-F360. https://doi.org/10 .1152/ajprenal.2000.278.3.F352.

Hoff, A. O., P. Catala-Lehnen, P. M. Thomas, M. Priemel, J. M. Rueger, I. Nasonkin, A. Bradley, M. R. Hughes, N. Ordonez, G. J. Cote, M. Amling, and R. F. Gagel. 2002. Increased bone mass is an unexpected phenotype associated with deletion of the calcitonin gene. J. Clin. Invest. 110:1849-1857. https://doi.org/10.1172/ JCI200214218.

Holcombe, S. J., L. Wisnieski, J. Gandy, B. Norby, and L. M. Sordillo. 2018. Reduced serum vitamin D concentrations in healthy early-lactation dairy cattle. J. Dairy Sci. 101:1488-1494. https:// doi.org/10.3168/jds.2017-13547.

Hollis, B. W., and R. L. Horst. 2007. The assessment of circulating $25(\mathrm{OH}) \mathrm{D}$ and $1,25(\mathrm{OH})_{2} \mathrm{D}$ : Where we are and where we are going. J. Steroid Biochem. Mol. Biol. 103:473-476. https://doi.org/ 10.1016/j.jsbmb.2006.11.004.

Horst, R. L., J. P. Goff, and T. A. Reinhardt. 2005. Adapting to the transition between gestation and lactation: Differences between rat, human and dairy cow. J. Mammary Gland Biol. Neoplasia 10:141-156. https://doi.org/10.1007/s10911-005-5397-x.

Horst, R. L., N. J. Koszewski, and T. A. Reinhardt. 1990. 1 Alphahydroxylation of 24-hydroxyvitamin $\mathrm{D}_{2}$ represents a minor physiological pathway for the activation of vitamin $\mathrm{D}_{2}$ in mammals. Biochemistry 29:578-582. https://doi.org/10.1021/bi00454a035.

Horst, R. L., and E. T. Littledike. 1982. Comparison of plasma concentrations of vitamin D and its metabolites in young and aged domestic animals. Comp. Biochem. Physiol. B 73:485-489. https:/ /doi.org/10.1016/0305-0491(82)90064-5.
Hove, K., R. L. Horst, and E. T. Littledike. 1983. Effects of 1 alpha-hydroxyvitamin $\mathrm{D}_{3}, 1,25$-dihydroxyvitamin $\mathrm{D}_{3}, 1,24,25$-trihydroxyvitamin $\mathrm{D}_{3}$, and $1,25,26$-trihydroxyvitamin $\mathrm{D}_{3}$ on mineral metabolism and 1,25-dihydroxyvitamin $\mathrm{D}$ concentrations in dairy cows. J. Dairy Sci. 66:59-66. https://doi.org/10.3168/jds.S0022 -0302(83)81753-6.

Hyde, M. L., M. R. Wilkens, and D. R. Fraser. 2019. In vivo measurement of strontium absorption from the rumen of dairy cows as an index of calcium absorption capacity. J. Dairy Sci. 102:5699-5705. https://doi.org/10.3168/jds.2018-16052.

Hymøller, L., and S. K. Jensen. 2010. Vitamin $\mathrm{D}_{3}$ synthesis in the entire skin surface of dairy cows despite hair coverage. J. Dairy Sci. 93:2025-2029. https://doi.org/10.3168/jds.2009-2991.

Hymøller, L., and S. K. Jensen. 2011. Vitamin $\mathrm{D}_{2}$ impairs utilization of vitamin $\mathrm{D}_{3}$ in high-yielding dairy cows in a cross-over supplementation regimen. J. Dairy Sci. 94:3462-3466. https://doi.org/10 $.3168 /$ jds.2010-4111.

Immler, R., S. I. Simon, and M. Sperandio. 2018. Calcium signalling and related ion channels in neutrophil recruitment and function. Eur. J. Clin. Invest. 48(Suppl. 2):e12964. https://doi.org/10.1111/ eci.12964.

Johannesson, A. J., and L. G. Raisz. 1983. Effects of low medium magnesium concentration on bone resorption in response to parathyroid hormone and 1,25-dihydroxyvitamin D in organ culture. Endocrinology 113:2294-2298. https://doi.org/10.1210/endo-113 $-6-2294$.

Jolliffe, D. A., R. T. Walton, C. J. Griffiths, and A. R. Martineau. 2016. Single nucleotide polymorphisms in the vitamin D pathway associating with circulating concentrations of vitamin D metabolites and non-skeletal health outcomes: Review of genetic association studies. J. Steroid Biochem. Mol. Biol. 164:18-29. https://doi .org/10.1016/j.jsbmb.2015.12.007.

Jørgensen, R. J., N. R. Nyengaard, S. Hara, J. M. Enemark, and P. H. Andersen. 1998. Rumen motility during induced hyper- and hypocalcaemia. Acta Vet. Scand. 39:331-338.

Kaya, S., J. Basta-Pljakic, Z. Seref-Ferlengez, R. J. Majeska, L. Cardoso, T. G. Bromage, Q. Zhang, C. R. Flach, R. Mendelsohn, S. Yakar, S. P. Fritton, and M. B. Schaffler. 2017. Lactation-induced changes in the volume of osteocyte lacunar-canalicular space alter mechanical properties in cortical bone tissue. J. Bone Miner. Res. 32:688-697. https://doi.org/10.1002/jbmr.3044.

Kerwin, A. L., C. M. Ryan, B. M. Leno, M. Jakobsen, P. Theilgaard, D. M. Barbano, and T. R. Overton. 2019. Effects of feeding synthetic zeolite A during the prepartum period on serum mineral concentration, oxidant status, and performance of multiparous Holstein cows. J. Dairy Sci. 102:5191-5207. https://doi.org/10 $.3168 /$ jds.2019-16272.

Kitazawa, S., K. Kajimoto, T. Kondo, and R. Kitazawa. 2003. Vitamin $\mathrm{D}_{3}$ supports osteoclastogenesis via functional vitamin $\mathrm{D}$ response element of human RANKL gene promoter. J. Cell. Biochem. 89:771-777. https://doi.org/10.1002/jcb.10567.

Kondo, T., R. Kitazawa, S. Maeda, and S. Kitazawa. 2004. 1 Alpha,25 dihydroxyvitamin $\mathrm{D}_{3}$ rapidly regulates the mouse osteoprotegerin gene through dual pathways. J. Bone Miner. Res. 19:1411-1419. https://doi.org/10.1359/JBMR.040604.

Kovacs, C. S. 2017. The skeleton is a storehouse of mineral that is plundered during lactation and (fully?) replenished afterwards. J. Bone Miner. Res. 32:676-680. https://doi.org/10.1002/jbmr.3090.

Krajisnik, T., P. Björklund, R. Marsell, Ö. Ljunggren, G. Åkerström, K. B. Jonsson, G. Westin, and T. E. Larsson. 2007. Fibroblast growth factor-23 regulates parathyroid hormone and $1 \alpha$-hydroxylase expression in cultured bovine parathyroid cells. J. Endocrinol. 195:125-131. https://doi.org/10.1677/JOE-07-0267.

Kumar, R., and J. R. Thompson. 2011. The regulation of parathyroid hormone secretion and synthesis. J. Am. Soc. Nephrol. 22:216-224. https://doi.org/10.1681/ASN.2010020186.

Laaksonen, M. M. L., T. A. Outila, M. U. M. Kärkkäinen, V. E. Kemi, H. J. Rita, M. Perola, L. M. Valsta, and C. J. E. Lamberg-Allardt. 2009. Associations of vitamin D receptor, calcium-sensing receptor and parathyroid hormone gene polymorphisms with calcium ho- 
meostasis and peripheral bone density in adult Finns. J. Nutrigenet. Nutrigenomics 2:55-63. https://doi.org/10.1159/000204960.

Laporta, J., K. P. Keil, C. M. Vezina, and L. L. Hernandez. 2014a. Peripheral serotonin regulates maternal calcium trafficking in mammary epithelial cells during lactation in mice. PLoS One 9:e110190. https://doi.org/10.1371/journal.pone.0110190.

Laporta, J., K. P. Keil, S. R. Weaver, C. M. Cronick, A. P. Prichard, T. D. Crenshaw, G. W. Heyne, C. M. Vezina, R. J. Lipinski, and L. L. Hernandez. 2014b. Serotonin regulates calcium homeostasis in lactation by epigenetic activation of hedgehog signaling. Mol. Endocrinol. 28:1866-1874. https://doi.org/10.1210/me.2014-1204.

Laporta, J., S. A. Moore, S. R. Weaver, C. M. Cronick, M. Olsen, A. P. Prichard, B. P. Schnell, T. D. Crenshaw, F. Penagaricano, R. M. Bruckmaier, and L. L. Hernandez. 2015. Increasing serotonin concentrations alter calcium and energy metabolism in dairy cows. J. Endocrinol. 226:43-55. https://doi.org/10.1530/JOE-14-0693.

Lassiter, W. E., C. W. Gottschalk, and M. Mylle. 1963. Micropuncture study of renal tubular reabsorption of calcium in normal rodents. Am. J. Physiol. 204:771-775. https://doi.org/10.1152/ajplegacy .1963.204.5.771.

Lean, I. J., P. J. DeGaris, D. M. McNeil, and E. Block. 2006. Hypocalcemia in dairy cows: Meta-analysis and dietary cation anion difference theory revisited. J. Dairy Sci. 89:669-684. https://doi .org/10.3168/jds.S0022-0302(06)72130-0.

Lean, I. J., J. E. P. Santos, E. Block, and H. M. Golder. 2019. Effects of prepartum dietary cation-anion difference intake on production and health of dairy cows: A meta-analysis. J. Dairy Sci. 102:21032133. https://doi.org/10.3168/jds.2018-14769.

Leclerc, H., and E. Block. 1989. Effects of reducing dietary cationanion balance for prepartum dairy cows with specific reference to hypocalcemic parturient paresis. Can. J. Anim. Sci. 69:411-423. https://doi.org/10.4141/cjas89-046.

Leno, B. M., R. C. Neves, I. M. Louge, M. D. Curler, M. J. Thomas, T. R. Overton, and J. A. A. McArt. 2018. Differential effects of a single dose of oral calcium based on postpartum plasma calcium concentration in Holstein cows. J. Dairy Sci. 101:3285-3302. https: //doi.org/10.3168/jds.2017-13164.

Leonhard-Marek, S., G. Becker, G. Breves, and B. Schröder. 2007. Chloride, gluconate, sulfate, and short-chain fatty acids affect calcium flux rates across the sheep forestomach epithelium. J. Dairy Sci. 90:1516-1526. https://doi.org/10.3168/jds.S0022 $-0302(07) 71637-5$.

Li, Y. C., M. Amling, A. E. Pirro, M. Priemel, J. Meuse, R. Baron, G. Delling, and M. B. Demay. 1998. Normalization of mineral ion homeostasis by dietary means prevents hyperparathyroidism, rickets, and osteomalacia, but not alopecia in vitamin D receptor-ablated mice. Endocrinology 139:4391-4396. https://doi.org/10.1210/endo .139.10.6262.

Liesegang, A. 2008. Influence of anionic salts on bone metabolism in periparturient dairy goats and sheep. J. Dairy Sci. 91:2449-2460. https://doi.org/10.3168/jds.2006-838.

Liesegang, A., C. Chiappi, J. Risteli, J. Kessler, and H. D. Hess. 2007. Influence of different calcium contents in diets supplemented with anionic salts on bone metabolism in periparturient dairy cows. J. Anim. Physiol. Anim. Nutr. (Berl.) 91:120-129. https://doi.org/10 $.1111 /$ j.1439-0396.2006.00651.x.

Lin, X., T. C. Brennan-Speranza, I. Levinger, and B. B. Yeap. 2018. Undercarboxylated osteocalcin: Experimental and human evidence for a role in glucose homeostasis and muscle regulation of insulin sensitivity. Nutrients 10:E847. https://doi.org/10.3390/ nu10070847.

Lomba, F., G. Chauvaux, E. Teller, L. Lengele, and V. Bienfet. 1978. Calcium digestibility in cows as influenced by the excess of alkaline ions over stable acid ions in their diets. Br. J. Nutr. 39:425-429. https://doi.org/10.1079/BJN19780058.

Lutz, T., and E. Scharrer. 1991. Effect of short-chain fatty acids on calcium absorption by the rat colon. Exp. Physiol. 76:615-618. https://doi.org/10.1113/expphysiol.1991.sp003530.

Ma, Y. L., R. L. Cain, D. L. Halladay, X. Yang, Q. Zeng, R. R. Miles, S. Chandrasekhar, T. J. Martin, and J. E. Onyia. 2001. Catabolic effects of continuous human PTH (1-38) in vivo is associated with sustained stimulation of RANKL and inhibition of osteoprotegerin and gene-associated bone formation. Endocrinology 142:40474054. https://doi.org/10.1210/endo.142.9.8356.

Mann, S., F. A. Leal Yepes, T. R. Overton, A. L. Lock, S. V. Lamb, J. J. Wakshlag, and D. V. Nydam. 2016. Effect of dry period dietary energy level in dairy cattle on volume, concentrations of immunoglobulin G, insulin, and fatty acid composition of colostrum. J. Dairy Sci. 99:1515-1526. https://doi.org/10.3168/jds.2015-9926.

Martinez, N., C. A. Risco, F. S. Lima, R. S. Bisinotto, L. F. Greco, E. S. Ribeiro, F. Maunsell, K. Galvao, and J. E. Santos. 2012. Evaluation of peripartal calcium status, energetic profile, and neutrophil function in dairy cows at low or high risk of developing uterine disease. J. Dairy Sci. 95:7158-7172. https://doi.org/10.3168/jds .2012-5812.

Martinez, N., R. M. Rodney, E. Block, L. L. Hernandez, C. D. Nelson, I. J. Lean, and J. E. P. Santos. 2018a. Effects of prepartum dietary cation-anion difference and source of vitamin $\mathrm{D}$ in dairy cows: Health and reproductive responses. J. Dairy Sci. 101:2563-2578. https://doi.org/10.3168/jds.2017-13740.

Martinez, N., R. M. Rodney, E. Block, L. L. Hernandez, C. D. Nelson, I. J. Lean, and J. E. P. Santos. 2018b. Effects of prepartum dietary cation-anion difference and source of vitamin D in dairy cows: Lactation performance and energy metabolism. J. Dairy Sci. 101:2544-2562. https://doi.org/10.3168/jds.2017-13739.

Martinez, N., L. D. Sinedino, R. S. Bisinotto, E. S. Ribeiro, G. C. Gomes, F. S. Lima, L. F. Greco, C. A. Risco, K. N. Galvão, D. Taylor-Rodriguez, J. P. Driver, W. W. Thatcher, and J. E. Santos. 2014. Effect of induced subclinical hypocalcemia on physiological responses and neutrophil function in dairy cows. J. Dairy Sci 97:874-887. https://doi.org/10.3168/jds.2013-7408.

Martinez, N., L. D. P. Sinedino, R. S. Bisinotto, R. Daetz, C. Lopera, C. A. Risco, K. N. Galvao, W. W. Thatcher, and J. E. P. Santos. 2016a. Effects of oral calcium supplementation on mineral and acid-base status, energy metabolites, and health of postpartum dairy cows. J. Dairy Sci. 99:8397-8416. https://doi.org/10.3168/ jds.2015-10527.

Martinez, N., L. D. P. Sinedino, R. S. Bisinotto, R. Daetz, C. A. Risco, K. N. Galvao, W. W. Thatcher, and J. E. P. Santos. 2016b. Effects of oral calcium supplementation on productive and reproductive performance in Holstein cows. J. Dairy Sci. 99:8417-8430. https:/ /doi.org/10.3168/jds.2015-10529.

McDermott, C. M., D. C. Beitz, E. T. Littledike, and R. L. Horst. 1985. Effects of dietary vitamin D3 on concentrations of vitamin $\mathrm{D}$ and its metabolites in blood plasma and milk of dairy cows. J. Dairy Sci. 68:1959-1967. https://doi.org/10.3168/jds.S0022 $-0302(85) 81057-2$.

Miltenburg, C. L., T. F. Duffield, D. Bienzle, E. L. Scholtz, and S. J. LeBlanc. 2016. Randomized clinical trial of a calcium supplement for improvement of health in dairy cows in early lactation. J. Dairy Sci. 99:6550-6562. https://doi.org/10.3168/jds.2016-10961.

Morgan, E. L., O. J. Mace, J. Affleck, and G. L. Kellett. 2007. Apical GLUT2 and $\mathrm{Ca}_{\mathrm{v}} 1.3$ : Regulation of rat intestinal glucose and calcium absorption. J. Physiol. 580:593-604. https://doi.org/10 .1113 /jphysiol.2006.124768.

Morgan, E. L., O. J. Mace, P. A. Helliwell, J. Affleck, and G. L. Kellett. 2003. A role for $\mathrm{Ca}_{\mathrm{v}} 1.3$ in rat intestinal calcium absorption. Biochem. Biophys. Res. Commun. 312:487-493. https://doi.org/10 $.1016 /$ j.bbrc.2003.10.138.

Mortensen, B. M., K. M. Gautvik, and J. O. Gordeladze. 1993. Bone turnover in rats treated with 1,25-dihydroxyvitamin D3, 25-hydroxyvitamin $\mathrm{D}_{3}$ or 24,25-dihydroxyvitamin $\mathrm{D}_{3}$. Biosci. Rep. 13:27-39. https://doi.org/10.1007/BF01138176.

NAHMS. 2002. Part I: Reference of Dairy Health and Management in the United States. USDA-APHIS-VS-CEAH-NAHMS, Fort Collins, CO.

NAHMS. 2007. Dairy 2007, Part I: Reference of Dairy Cattle Health and Management Practices in the United States. USDA-APHISVS-CEAH-NAHMS, Fort Collins, CO.

NAHMS. 2014. Dairy 2014, Health and Management Practices on U.S. Dairy Operations. USDA-APHIS-VS-CEAH-NAHMS, Fort Collins, CO. 
Negri, A. L. 2015. Role of claudins in renal calcium handling. Nefrologia 35:347-352. https://doi.org/10.1016/j.nefro.2015.06.011.

Nelson, C. D., J. D. Lippolis, T. A. Reinhardt, R. E. Sacco, J. L. Powell, M. E. Drewnoski, M. O'Neil, D. C. Beitz, and W. P. Weiss. 2016. Vitamin D status of dairy cattle: Outcomes of current practices in the dairy industry. J. Dairy Sci. 99:10150-10160. https:// doi.org/10.3168/jds.2016-11727.

Nelson, C. D., K. E. Merriman, M. B. Poindexter, M. F. Kweh, and L. P. Blakely. 2018. Symposium review: Targeting antimicrobial defenses of the udder through an intrinsic cellular pathway. J. Dairy Sci. 101:2753-2761. https://doi.org/10.3168/jds.2017-13426.

Neves, R. C., B. M. Leno, K. D. Bach, and J. A. A. McArt. 2018b. Epidemiology of subclinical hypocalcemia in early-lactation Holstein dairy cows: The temporal associations of plasma calcium concentration in the first 4 days in milk with disease and milk production. J. Dairy Sci. 101:9321-9331. https://doi.org/10.3168/ jds.2018-14587.

Neves, R. C., B. M. Leno, M. D. Curler, M. J. Thomas, T. R. Overton, and J. A. A. McArt. 2018a. Association of immediate postpartum plasma calcium concentration with early-lactation clinical diseases, culling, reproduction, and milk production in Holstein cows. J. Dairy Sci. 101:547-555. https://doi.org/10.3168/jds.2017-13313.

Neville, M. C., and C. D. Watters. 1983. Secretion of calcium into milk. J. Dairy Sci. 66:371-380. https://doi.org/10.3168/jds.S0022 -0302(83)81802-5.

Oehlschlaeger, V., M. Wilkens, B. Schroeder, S. Daenicke, and G. Breves. 2014. Effects of 25-hydroxyvitamin $\mathrm{D}_{3}$ on localisation and extent of gastrointestinal calcium absorption in dairy cattle. Anim. Prod. Sci. 54:1394-1398. https://doi.org/10.1071/AN14344.

Oetzel, G. R. 1991. Meta-analysis of nutritional risk factors for milk fever in dairy cattle. J. Dairy Sci. 74:3900-3912. https://doi.org/ 10.3168/jds.S0022-0302(91)78583-4.

Oetzel, G. R., and B. E. Miller. 2012. Effect of oral calcium bolus supplementation on early-lactation health and milk yield in commercial dairy herds. J. Dairy Sci. 95:7051-7065. https://doi.org/ 10.3168/jds.2012-5510.

Pacheco, H. A., S. da Silva, A. Sigdel, C. K. Mak, K. N. Galvão, R. A. Texeira, L. T. Dias, and F. Peñagaricano. 2018. Gene mapping and gene-set analysis for milk fever incidence in Holstein dairy cattle. Front. Genet. 9:465. https://doi.org/10.3389/fgene.2018.00465.

Peng, J. B., X. Z. Chen, U. V. Berger, P. M. Vassilev, H. Tsukaguchi, E. M. Brown, and M. A. Hediger. 1999. Molecular cloning and characterization of a channel-like transporter mediating intestinal calcium absorption. J. Biol. Chem. 274:22739-22746. https://doi .org/10.1074/jbc.274.32.22739.

Peterson, A. B., M. W. Orth, J. P. Goff, and D. K. Beede. 2005. Periparturient responses of multiparous Holstein cows fed different dietary phosphorus concentrations prepartum. J. Dairy Sci. 88:35823594. https://doi.org/10.3168/jds.S0022-0302(05)73043-5.

Poindexter, M. B., M. F. Kweh, R. Zimpel, J. Zuniga, C. Lopera, M. Zenobi, Y. Jiang, M. Engstrom, P. Celi, J. E. P. Santos, and C. D. Nelson. 2020. Feeding 25-hydroxyvitamin $\mathrm{D}_{3}$ increases serum mineral concentrations and alters mammary immunity of lactating dairy cows. J. Dairy Sci. https://doi.org/10.3168/jds.2019-16999. 103:805-822

Poindexter, M. B., A. Vieira-Neto, A. Husnain, R. Zimpel, A. Faccenda, A. Sanches de Avila, A. Silva, P. Celi, C. Cortinhas, J. E. P. Santos, and C. D. Nelson. 2019. Effects of dose and source of vitamin $\mathrm{D}$ on mineral homeostasis and performance in transition dairy cows. J. Dairy Sci. 102(Suppl. 1):340 (Abstr.).

Reinhardt, T. A., and R. L. Horst. 1999. $\mathrm{Ca}^{2+}$-ATPases and their expression in the mammary gland of pregnant and lactating rats. Am. J. Physiol. 276:C796-C802. https://doi.org/10.1152/ajpcell 1999.276.4.C796

Reinhardt, T. A., R. L. Horst, and J. P. Goff. 1988. Calcium, phosphorus and magnesium homeostasis in ruminants. Vet. Clin. North Am. Food Anim. Pract. 4:331-350. https://doi.org/10.1016/S0749 -0720(15)31052-5.

Reinhardt, T. A., J. D. Lippolis, B. J. McCluskey, J. P. Goff, and R. L. Horst. 2011. Prevalence of subclinical hypocalcemia in dairy herds. Vet. J. 188:122-124. https://doi.org/10.1016/j.tvjl.2010.03.025.
Reinhardt, T. A., J. D. Lippolis, G. E. Shull, and R. L. Horst. 2004. Null mutation in the gene encoding plasma membrane $\mathrm{Ca}^{2+}$-ATPase isoform 2 impairs calcium transport into milk. J. Biol. Chem. 279:42369-42373. https://doi.org/10.1074/jbc.M407788200.

Roche, J. R., D. E. Dalley, and F. P. O'Mara. 2007. Effect of a metabolically created systemic acidosis on calcium homeostasis and the diurnal variation in urine $\mathrm{pH}$ in the non-lactating pregnant dairy cow. J. Dairy Res. 74:34-39. https://doi.org/10.1017/ S0022029906002123.

Roche, J. R., A. Heiser, M. A. Crookenden, C. R. Burke, S. A. Rutner, B. Kuhn-Sherlock, and C. V. C. Phyn. 2018. The effect of feeding synthetic zeolite A prepartum on indices of mineral and metabolic status, milk production and reproduction in grazing dairy cows. J. Dairy Sci. 101(Suppl. 2):175. (Abstr.)

Rodney, R. M., N. Martinez, E. Block, L. L. Hernandez, P. Celi, C. D. Nelson, J. E. P. Santos, and I. J. Lean. 2018a. Effects of prepartum dietary cation-anion difference and source of vitamin D in dairy cows: Vitamin D, mineral, and bone metabolism. J. Dairy Sci 101:2519-2543. https://doi.org/10.3168/jds.2017-13737.

Rodney, R. M., N. Martinez, P. Celi, E. Block, P. C. Thomson, G. Wijffels, D. R. Fraser, J. E. P. Santos, and I. J. Lean. 2018b. Associations between bone and energy metabolism in cows fed diets differing in level of dietary cation-anion difference and supplemented with cholecalciferol or calcidiol. J. Dairy Sci. 101:6581-6601. https: //doi.org/10.3168/jds.2017-14033.

Rodríguez, E. M., A. Aris, and A. Bach. 2017. Associations between subclinical hypocalcemia and postparturient diseases in dairy cows. J. Dairy Sci. 100:7427-7434. https://doi.org/10.3168/jds .2016-12210.

Rodríguez, E. M., A. Bach, M. Devant, and A. Aris. 2016. Is calcitonin an active hormone in the onset and prevention of hypocalcemia in dairy cattle? J. Dairy Sci. 99:3023-3030. https://doi.org/10.3168/ jds.2015-10229.

Romo, G. A., R. O. Kellems, K. Powell, and M. V. Wallentine. 1991. Some blood minerals and hormones in cows fed variable mineral levels and ionic balance. J. Dairy Sci. 74:3068-3077. https://doi .org/10.3168/jds.S0022-0302(91)78492-0.

Rosendahl, J., H. S. Braun, K. T. Schrapers, H. Martens, and F. Stumpff. 2016. Evidence for the functional involvement of members of the TRP channel family in the uptake of $\mathrm{Na}^{+}$and $\mathrm{NH}_{4}{ }^{+}$by the ruminal epithelium. Pflugers Arch. 468:1333-1352. https://doi .org/10.1007/s00424-016-1835-4.

Saji, F., T. Shigematsu, T. Sakaguchi, M. Ohya, H. Orita, Y. Maeda, M. Ooura, T. Mima, and S. Negi. 2010. Fibroblast growth factor 23 production in bone is directly regulated by $1 \alpha, 25$-dihydroxyvitamin D, but not PTH. Am. J. Physiol. Renal Physiol. 299:F1212-F1217. https://doi.org/10.1152/ajprenal.00169.2010.

Santos, J. E. P., I. J. Lean, H. Golder, and E. Block. 2019. Meta-analysis of the effects of prepartum dietary cation-anion difference on performance and health of dairy cows. J. Dairy Sci. 102:2134-2154. https://doi.org/10.3168/jds.2018-14628.

Schiavi, S. C., and R. Kumar. 2004. The phosphatonin pathway: New insights in phosphate homeostasis. Kidney Int. 65:1-14. https:// doi.org/10.1111/j.1523-1755.2004.00355.x.

Schonewille, J. T., A. T. Van't Klooster, A. Dirkzwager, and A. C. Beynen. 1994. Stimulatory effect of an anion(chloride)-rich ration on apparent calcium absorption in dairy cows. Livest. Prod. Sci. 40:233-240. https://doi.org/10.1016/0301-6226(94)90091-4.

Schrapers, K. T., G. Sponder, F. Liebe, H. Liebe, and F. Stumpff. 2018. The bovine TRPV3 as a pathway for the uptake of $\mathrm{Na}^{+}$ $\mathrm{Ca}^{2+}$, and $\mathrm{NH}_{4}^{+}$. PLoS One 13:e0193519. https://doi.org/10.1371/ journal.pone.0193519.

Schröder, B., and G. Breves. 2006. Mechanisms and regulation of calcium absorption from the gastrointestinal tract in pigs and ruminants: Comparative aspects with special emphasis on hypocalcemia in dairy cows. Anim. Health Res. Rev. 7:31-41. https://doi .org/10.1017/S1466252307001144.

Schröder, B., W. Goebel, K. Huber, and G. Breves. 2001. No effect of vitamin $\mathrm{D}_{3}$ treatment on active calcium absorption across ruminal epithelium of sheep. J. Vet. Med. A Physiol. Pathol. Clin. Med. 48:353-363. https://doi.org/10.1046/j.1439-0442.2001.00369.x. 
Schröder, B., M. R. Wilkens, G. E. Ricken, S. Leonhard-Marek, D. R. Fraser, and G. Breves. 2015. Calcium transport in bovine rumen epithelium as affected by luminal Ca concentrations and Ca sources. Physiol. Rep. 3:e12615. https://doi.org/10.14814/phy2.12615.

Shappell, N. W., J. H. Herbein, L. J. Deftos, and R. J. Aiello. 1987. Effects of dietary calcium and age on parathyroid hormone, calcitonin and serum and milk minerals in the periparturient dairy cow. J. Nutr. 117:201-207. https://doi.org/10.1093/jn/117.1.201.

Shimada, T., H. Hasegawa, Y. Yamazaki, T. Muto, R. Hino, Y. Takeuchi, T. Fujita, K. Nakahara, S. Fukumoto, and T. Yamashita. 2004b. FGF23 is a potent regulator of vitamin D metabolism and phosphate homeostasis. J. Bone Miner. Res. 19:429-435. https:// doi.org/10.1359/JBMR.0301264.

Shimada, T., M. Kakitani, Y. Yamazaki, H. Hasegawa, Y. Takeuchi, T. Fujita, S. Fukumoto, K. Tomizuka, and T. Yamashita. 2004a. Targeted ablation of Fgf23 demonstrates an essential physiological role of FGF23 in phosphate and vitamin D metabolism. J. Clin. Invest. 113:561-568. https://doi.org/10.1172/JCI200419081.

Slater, C. J., E. L. Endres, S. R. Weaver, A. A. Cheng, M. R. Lauber, S. F. Endres, E. Olstad, A. DeBruin, P. M. Crump, E. Block, and L. L. Hernandez. 2018. Interaction of 5-hydroxy-l-tryptophan and negative dietary cation-anion difference on calcium homeostasis in multiparous peripartum dairy cows. J. Dairy Sci. 101:5486-5501. https://doi.org/10.3168/jds.2017-13938.

Smith, P. N., M. Padilla, R. H. Wasserman, and F. A. Kallfelz. 1982. Calcium and 24,25-dihydroxyvitamin D: inverse relation in cows with parturient paresis. Calcif. Tissue Int. 34:564-566. https://doi .org/10.1007/BF02411305.

Sorge, U. S., T. Molitor, J. Linn, D. Gallaher, and S. W. Wells. 2013. Cow-level association between serum 25-hydroxyvitamin D concentration and Mycobacterium avium subspecies paratuberculosis antibody seropositivity: A pilot study. J. Dairy Sci. 96:1030-1037. https://doi.org/10.3168/jds.2012-5929.

Sutton, R. A., N. L. Wong, and J. H. Dirks. 1979. Effects of metabolic acidosis and alkalosis on sodium and calcium transport in the dog kidney. Kidney Int. 15:520-533. https://doi.org/10.1038/ki.1979 .67 .

Taylor, M. S., K. F. Knowlton, M. L. McGilliard, W. S. Swecker, J. D. Ferguson, Z. Wu, and M. D. Hanigan. 2009. Dietary calcium has little effect on mineral balance and bone mineral metabolism through twenty weeks of lactation in Holstein cows. J. Dairy Sci. 92:223-237. https://doi.org/10.3168/jds.2008-1345.

Thilsing, T., R. J. Jorgensen, and H. D. Poulsen. 2006. In vitro binding capacity of zeolite A to calcium, phosphorus and magnesium in rumen fluid as influenced by changes in $\mathrm{pH}$. J. Vet. Med. A Physiol. Pathol. Clin. Med. 53:57-64. https://doi.org/10.1111/j .1439-0442.2006.00798.x.

Thilsing-Hansen, T., R. J. Jorgensen, J. M. Enemark, and T. Larsen. 2002. The effect of zeolite A supplementation in the dry period on periparturient calcium, phosphorus, and magnesium homeostasis. J. Dairy Sci. 85:1855-1862. https://doi.org/10.3168/jds.S0022 -0302(02)74259-8.

Trouvin, A. P., and V. Goeb. 2010. Receptor activator of nuclear factor-kappaB ligand and osteoprotegerin: maintaining the balance to prevent bone loss. Clin. Interv. Aging 5:345-354.

Tsiamadis, V., G. Banos, N. Panousis, M. Kritsepi-Konstantinou, G. Arsenos, and G. E. Valergakis. 2016a. Genetic parameters of calcium, phosphorus, magnesium, and potassium serum concentrations during the first 8 days after calving in Holstein cows. J. Dairy Sci. 99:5535-5544. https://doi.org/10.3168/jds.2015-10787.

Tsiamadis, V., G. Banos, N. Panousis, M. Kritsepi-Konstantinou, G. Arsenos, and G. E. Valergakis. 2016b. Genetic parameters of subclinical macromineral disorders and major clinical diseases in postparturient Holstein cows. J. Dairy Sci. 99:8901-8914. https://doi .org/10.3168/jds.2015-10789.

Uppal, S. K., K. Wolf, and H. Martens. 2003. The effect of short chain fatty acids on calcium flux rates across isolated rumen epithelium of hay-fed and concentrate-fed sheep. J. Anim. Physiol. Anim. Nutr. (Berl.) 87:12-20. https://doi.org/10.1046/j.1439-0396.2003 .00401.x.
Valldecabres, A., J. A. A. Pires, and N. Silva-Del-Rio. 2018. Effect of prophylactic oral calcium supplementation on postpartum mineral status and markers of energy balance of multiparous Jersey cows. J. Dairy Sci. 101:4460-4472. https://doi.org/10.3168/jds.2017 $-12917$.

van Abel, M., J. G. Hoenderop, A. W. van der Kemp, J. P. van Leeuwen, and R. J. Bindels. 2003. Regulation of the epithelial Ca2+ channels in small intestine as studied by quantitative mRNA detection. Am. J. Physiol. Gastrointest. Liver Physiol. 285:G78-G85. https://doi.org/10.1152/ajpgi.00036.2003.

van de Braak, A. E., A. T. van 't Klooster, and A. Malesteint. 1986. Influence of prepartum calcium intake on calcium mobilization rate around parturition in dairy cows fed at a high prepartum feeding level. Vet. Q. 8:24-37. https://doi.org/10.1080/01652176 .1986 .9694014$.

van Doorn, D. A., M. E. van der Spek, H. Everts, H. Wouterse, and A. C. Beynen. 2004. The influence of calcium intake on phosphorus digestibility in mature ponies. J. Anim. Physiol. Anim. Nutr. (Berl.) 88:412-418. https://doi.org/10.1111/j.1439-0396 2004.00503.x.

VanHouten, J. N., M. C. Neville, and J. J. Wysolmerski. 2007. The calcium-sensing receptor regulates plasma membrane calcium adenosine triphosphatase isoform 2 activity in mammary epithelial cells: A mechanism for calcium-regulated calcium transport into milk. Endocrinology 148:5943-5954. https://doi.org/10.1210/en .2007-0850.

VanHouten, J. N., and J. J. Wysolmerski. 2007. Transcellular calcium transport in mammary epithelial cells. J. Mammary Gland Biol. Neoplasia 12:223-235. https://doi.org/10.1007/s10911-007-9057-1.

VanHouten, J. N., and J. J. Wysolmerski. 2013. The calcium-sensing receptor in the breast. Best Pract. Res. Clin. Endocrinol. Metab. 27:403-414. https://doi.org/10.1016/j.beem.2013.02.011.

Venjakob, P. L., L. Pieper, W. Heuwieser, and S. Borchardt. 2018. Association of postpartum hypocalcemia with early-lactation milk yield, reproductive performance, and culling in dairy cows. J. Dairy Sci. 101:9396-9405. https://doi.org/10.3168/jds.2017-14202.

Vieira-Neto, A., I. M. R. Leao, J. G. Prim, R. Zimpel, K. V. de Almeida, M. M. Nehme, J. Bollatti, A. C. M. Silva, A. Revilla-Ruiz, C. D. Nelson, and J. E. P. Santos. 2019. Effect of duration of exposure to diets differing in DCAD on calcium metabolism after a parathyroid hormone challenge in dairy cows. J. Dairy Sci 102(Suppl. 1):15. (Abstr.)

Vieira-Neto, A., I. R. P. Lima, F. Lopes Jr., C. Lopera, R. Zimpel, L. D. P. Sinedino, K. C. Jeong, K. Galvão, W. W. Thatcher, C. D. Nelson, and J. E. P. Santos. 2017. Use of calcitriol to maintain postpartum blood calcium and improve immune function in dairy cows. J. Dairy Sci. 100:5805-5823. https://doi.org/10.3168/ jds.2016-12506.

Weaver, S. R., A. P. Prichard, E. L. Endres, S. A. Newhouse, T. L. Peters, P. M. Crump, M. S. Akins, T. D. Crenshaw, R. M. Bruckmaier, and L. L. Hernandez. 2016. Elevation of circulating serotonin improves calcium dynamics in the peripartum dairy cow. J. Endocrinol. 230:105-123. https://doi.org/10.1530/JOE-16-0038.

Weiss, W. P., E. Azem, W. Steinberg, and T. A. Reinhardt. 2015. Effect of feeding 25-hydroxyvitamin $\mathrm{D}_{3}$ with a negative cation-anion difference diet on calcium and vitamin $\mathrm{D}$ status of periparturient cows and their calves. J. Dairy Sci. 98:5588-5600. https://doi.org/ $10.3168 /$ jds.2014-9188.

Whiting, S. J., and G. A. Quamme. 1984. Effects of dietary calcium on renal calcium, magnesium and phosphate excretion by the rabbit. Miner. Electrolyte Metab. 10:217-221.

Wilkens, M. R., K. Elfers, M. Schmicke, G. Breves, and A. S. MuscherBanse. 2018. Dietary nitrogen and calcium modulate CYP27B1 expression in young goats. Domest. Anim. Endocrinol. 64:70-76. https://doi.org/10.1016/j.domaniend.2018.03.005.

Wilkens, M. R., N. Mrochen, G. Breves, and B. Schröder. 2010. Effects of 1,25-dihydroxyvitamin $\mathrm{D}_{3}$ on calcium and phosphorus homeostasis in sheep fed diets either adequate or restricted in calcium content. Domest. Anim. Endocrinol. 38:190-199. https://doi.org/ 10.1016/j.domaniend.2009.10.003. 
Wilkens, M. R., N. Mrochen, G. Breves, and B. Schröder. 2011. Gastrointestinal calcium absorption in sheep is mostly insensitive to an alimentary induced challenge of calcium homeostasis. Comp. Biochem. Physiol. B Biochem. Mol. Biol. 158:199-207. https://doi .org/10.1016/j.cbpb.2010.11.008.

Wilkens, M. R., I. Oberheide, B. Schröder, E. Azem, W. Steinberg, and G. Breves. 2012a. Influence of the combination of 25-hydroxyvitamin $D_{3}$ and a diet negative in cation-anion difference on peripartal calcium homeostasis of dairy cows. J. Dairy Sci. 95:151-164. https: //doi.org/10.3168/jds.2011-4342.

Wilkens, M. R., C. Praechter, G. Breves, and B. Schröder. 2016. Stimulating effects of a diet negative in dietary cation-anion difference on calcium absorption from the rumen in sheep. J. Anim. Physiol. Anim. Nutr. (Berl.) 100:156-166. https://doi.org/10.1111/jpn .12296 .

Wilkens, M. R., J. Richter, D. R. Fraser, A. Liesegang, G. Breves, and B. Schröder. 2012b. In contrast to sheep, goats adapt to dietary calcium restriction by increasing intestinal absorption of calcium. Comp. Biochem. Physiol. A Mol. Integr. Physiol. 163:396-406. https://doi.org/10.1016/j.cbpa.2012.06.011.

Wilms, J., G. Wang, J. Doelman, M. Jacobs, and J. Martin-Tereso. 2019. Intravenous calcium infusion in a calving protocol disrupts calcium homeostasis compared with an oral calcium supplement. J. Dairy Sci. 102:6056-6064. https://doi.org/10.3168/jds.2018-15754.

Wysolmerski, J. J. 2010. Interactions between breast, bone, and brain regulate mineral and skeletal metabolism during lactation. Ann.
N. Y. Acad. Sci. 1192:161-169. https://doi.org/10.1111/j.1749 $-6632.2009 .05249 . \mathrm{x}$

Yamagishi, N., M. Miyazaki, and Y. Naito. 2006. The expression of genes for transepithelial calcium-transporting proteins in the bovine duodenum. Vet. J. 171:363-366. https://doi.org/10.1016/j .tvjl.2004.10.021.

Yeh, B. I., T. J. Sun, J. Z. Lee, H. H. Chen, and C. L. Huang. 2003. Mechanism and molecular determinant for regulation of rabbit transient receptor potential type 5 (TRPV5) channel by extracellular pH. J. Biol. Chem. 278:51044-51052. https://doi.org/10 .1074/jbc.M306326200.

Zimpel, R., M. B. Poindexter, A. Vieira-Neto, E. Block, C. D. Nelson, C. R. Staples, W. W. Thatcher, and J. E. P. Santos. 2018. Effect of dietary cation-anion difference on acid-base status and dry matter intake in dry pregnant cows. J. Dairy Sci. 101:8461-8475. https:// doi.org/10.3168/jds.2018-14748.

\section{ORCIDS}

Mirja R. Wilkens @ https://orcid.org/0000-0003-1734-5024

Corwin D. Nelson (ㄴ) https://orcid.org/0000-0003-0195-5610

Laura L. Hernandez @i https://orcid.org/0000-0001-7591-5203

Jessica A. A. McArt (i) https://orcid.org/0000-0001-5654-9172 